\title{
PEMANFAATAN TEKNOLOGI INFORMASI DALAM PEMBELAJARAN KLASIFIKASI\& KODEFIKASI PENYAKIT DAN MASALAH TERKAIT
}

\author{
$\mathrm{Nury}$ a t i \\ Dosen Pada Program Studi D3 Rekam Medis Sekolah Vokasi UGM \\ nur3yati@yahoo.com
}

\begin{abstract}
ABSTRAK
Klasifikasi dan kodefikasi penyakit dan masalah terkait merupakan salah satu kompetensi yang harus dicapai oleh Perekam Medis. Hal tersebut tertuang dalam Kepmenkes RI No 377 tahun 2007 tentang Standar Profesi Perekam Medis dan Informasi Kesehatan dengan Deskripsi Kompetensi: Perekam Medis mampu menetapkan kode penyakit dan tindakan dengan tepat sesuai klasifikasi yang diberlakukan di Indonesia (ICD-10) tentang penyakit dan tindakan medis dalam pelayanan dan manajemen kesehatan. Permasalahan yang ada pada saat ini adalah masih terbatasnya SDM yang benar-benar terampil dalam menetapkan kode, minimal SDM tersebut telah menempuh pendidikan Diploma 3 Perekam Medis dan Informasi Kesehatan, masih minimnya Dosen/ instruktur, alat bantu dan media dalam pembelajaran klasifikasi dan kodefikasi penyakit di perguruan tinggi Perekam Medis dan Informasi Kesehatan.

Oleh karena itu dalam penelitian ini akan dibahas mengenai permasalahan dan upaya dalam pembelajaran tersebut. Dalam hal ini terkait pemanfaatan teknologi informasi dalam pembelajaran klasifikasi dan kodefikasi penyakit dan masalah terkait.
\end{abstract}

Kata Kunci: Teknologi Informasi, Klasifikasi dan Kodefikasi, Rekam medis

\section{PENDAHULUAN}

Pembelajaran merupakan sebuah upaya yang terdiri dari serangkaian proses belajar mengajar yang mempunyai tujuan untuk memperoleh pengetahuan, pandangan, dan ketrampilan yang diperlukan untuk menghasilkan suatu sikap dan perilaku tertentu ketika menghadapi suatu keadaan tertentu $u^{1,3}$. Proses pembelajaran merupakan sebuah sistem yang terdiri atas berbagai komponen yang saling berkaitan, sehingga keberhasilan pembelajaran sangat tergantung dari berbagai komponen tersebut. Setting atau tempat dilaksanakannya pendidikan dapat dilakukan di sekolah, masyarakat, tempat kerja, tempat pelayanan kesehatan, dan langsung ke pribadi ${ }^{2}$, sehingga di manapun tempatnya, proses pendidikan dapat dilaksanakan. Pengajar maupun sarana pendidikan dalam proses belajar-mengajar sebaiknya didesain dengan metode yang menarik serta menggunakan alat bantu yang dapat menunjang efektifitas pembelajaran, misalnya dengan menggunakan metode $e$ learning, sehingga dapat menjangkau peserta didik yang jauh serta lebih banyak jumlahnya.

Pemanfaatan teknologi informasi dalam proses pembelajaran merupakan salah satu alat bantu pembelajaran yang dapat meningkatkan pengetahuan, keterampilan, serta metode yang efektif ${ }^{4,5,6}$.

Salah satu kompetensi perekam medis adalah memiliki kemampuan menentukan kode diagnosis dan tindakan sesuai klasifikasi internasional. Tugas memberi 
kode penyakit harus dilaksanakan oleh petugas perekam medis, hal ini sesuai dengan Peraturan Menteri Kesehatan No. 377 Tahun 2007 tentang Kompetensi Perekam Medis dan Informasi Kesehatan, oleh karena itu petugas tersebut harus mampu membaca dan memahami terminologi kedokteran dalam menggunakan ICD-10.

Oleh karena itu perlu dikembangkan metode pembelajaran mengenai terminologi medis dan klasifikasi penyakit (ICD-10) yang dapat dimanfaatkan baik oleh mahasiswa, peserta pelatihan maupun petugas pelayanan kesehatan. Salah satu metode tersebut adalah pengembangan aplikasi berbasis komputer dengan metode e-learning yang dapat memberikan kemudahan dan kemanfaatan serta pemahaman akan terminologi medis dan klasifikasi penyakit bagi pengguna. Manfaat dari penggunaan multimedia dalam pembelajaran dapat menghindari kesenjangan baik kesenjangan jarak maupun komunikasi diantara pengajar dan peserta didik, dapat menjadi alat simulasi pemecahan masalah melalui studi kasus serta latihan-latihan yang didesain secara interaktif ${ }^{4}$. Selain itu pembelajaran berbasis multimedia dapat dilakukan secara mandiri tanpa harus didampingi pengajar secara terus menerus karena tersedianya petunjuk penggunaan serta dilengkapi menu yang dapat menunjang pemahaman pengguna.

\section{Permasalahan Yang Di Hadapi}

Berdasarkan Standar Kompetensi Perekam Medis dan Informasi Kesehatan tahun 2007 dinyatakan bahwa Perekam Medis mampu menetapkan kode penyakit dan tindakan dengan tepat sesuai klasifikasi yang diberlakukan di Indonesia (ICD-10) tentang penyakit dan tindakan medis dalam pelayanan dan manajemen kesehatan. Akan tetapi beberapa kesulitan masih menghambat terhadap pemahaman dan kecepatan pemilihan kode bagi petugas dan mahasiswa. Permasalahan yang di hadapi adalah sebagai berikut:

1. Minimnya sarana dan prasarana dalam menunjang mutu pendidikan, dalam hal ini terkait sarana pembelajaran yang interaktif, misalnya program pembelajaran klasifikasi dan kodefikasi dengan menggunakan teknologi informasi;

2. Kurikulum klasifikasi dan kodefikasi belum siap dalam menyongsong masa yang akan datang, yaitu masih terbatas pada penyampaian materi secara konvensional serta belum mengembangkan dan menerapkan kurikulum berbasis teknologi informasi;

3. Terbatasnya pengajar yang memahami terminologi medis dan klasifikasi penyakit (ICD), dalam hal ini perguruan tinggi Rekam Medis di Indonesia masih terbatas dari segi jumlah dosen pengajar yang berlatar belakang D3 Rekam Medis dengan S2 Kesehatan. Serta belum tersedia sertifikasi bagi tenaga pengajar terkait klasifikasi dan kodefikasi penyakit dan masalah terkait; 
4. Terbatasnya pustaka terminologi medis dan klasifikasi penyakit (ICD-10) yang menggunakan bahasa pengantarnya adalah Bahasa Indonesia. Pustaka-pustaka tersebut banyak yang menggunakan pengantar bahasa Inggris;

5. Terbatasnya contoh-contoh kuis, latihanlatihan yang dapat digunakan untuk memperdalam pemahaman materi klasifikasi dan kodefikasi penyakit dan masalah terkait;

6. Masih terbatas pada pembelajaran dalam kelas (metode konvensional)

7. Kegiatan belajar mengajar masih kurang profesional, kurang efektif dan kurang mendapat perhatian dari pengelola program;

8. Rendahnya motivasi belajar dari mahasiswa untuk menggali informasi selain dari pengajar terkait klasifikasi dan kodefikasi penyakit dan masalah terkai;

9. Materi klasifikasi dan kodefikasi penyakit dan masalah terkait tidak dapat hanya diberikan dalam kelas, akan tetapi akan lebih menarik jika menggunakan program pembelajaran dengan bantuan komputer, sehingga dapat mengurangi kejenuhan dan kebosanan dari mahasiswa;

10. Tenaga pengajar masih menggunakan kasus tertulis, masih jarang yang langsung menggunakan kasus dari berkas rekam medis pasien.

\section{Upaya Pembelajaran}

Upaya pembelajaran untuk mengurangi gap masalah yang sudah disebutkan diatas adalah salah satunya dengan memanfaatkan teknologi informasi. Hal ini WHO sudahmempublikasikanwebsite terkaitpembelajaran klasifikasi dan kodefikasi penyakit. Alamat website dapat diunduh melalui :

1. ICD-10 general \& morbidity coding online training package,

http://apps.who.int/classifications/apps/ic d/ICD10Training/ICD-

10\%20training/Start/index.html.

Dalam aplikasi tersebut, disediakan secara lengkap mulai dari tujuan pembelajaran sampai dengan latihan menentukan kode. Dalam aplikasi ini dijelaskan secara detail kekhususan dari tiap bab dalam ICD-10 (bab I - XXII), selain itu dilengkapi dengan materimateri yang terdapat pada volume 2 ICD-10 antara lain terkait informasi aturan tentang morbiditas dan mortalitas, serta bagaimana membuat sertifikat kematian. Aplikasi ini didesain cukup interaktif, yang mana materi dilengkapi dengan gambar dan kasus. Berikut tampilan dari website tersebut:

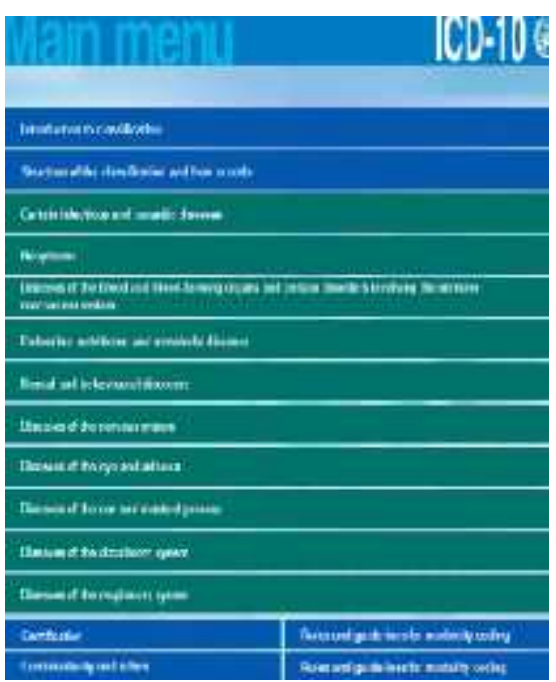

Gambar 1.Halaman Menu dari ICD10Training 
2. ICD-10 mortality coding online training package,

http://apps.who.int/classifications/apps/ic d/ICD10Training/ICD-

10\%20Death\%20Certificate/html/index.h $\underline{\mathrm{tml}}$

WHO juga sudah menyediakan training khusus untuk sertifikat kematian, berikut tampilan utamanya:

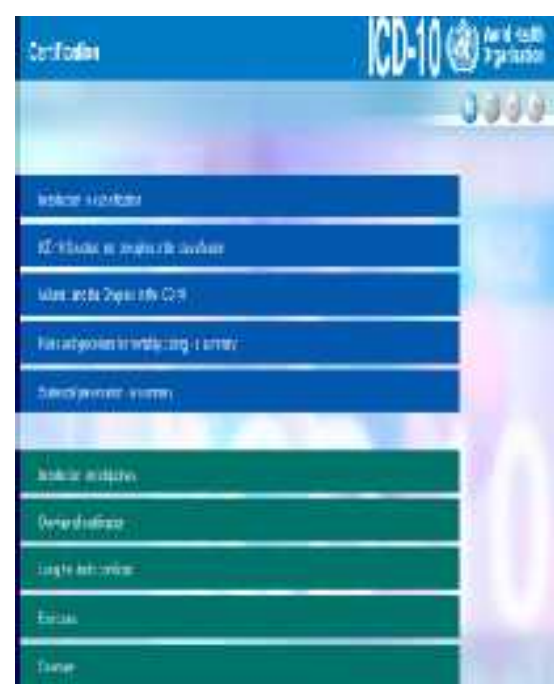

Gambar 2. Tampilan Halaman Utama Training ICD-10-Sertifikat Kematian

Selain menggunakan sumberpembelajaran yang online, sebaiknya perlu dikembangkan aplikasi yang dapat menampung semua kompetensi yang harus dicapai oleh mahasiswa maupun petugas rekam medis, diantaranya membuat aplikasi dalam bahasa Indonesia disertai dengan contoh-contoh latihan.

\section{Penerapan Aplikasi Komputerisasi (eLearning)}

Perguruan tinggi Rekam Medis banyak yang sudahmenerapkan pembelajaran dengan menggunakan teknologi informasi, salah satunya adalah bentuk e-Learning.
Perguruan tinggi tersebut adalah salah satunya adalah Universitas Gadjah Mada dan Universitas Esa Unggul. Halaman tersebut dapat diunduh melalui alamat: http://elisa.ugm.ac.id/danhttp://element.esau nggul.ac.id/. Untuk tampilan halaman elearning sebagai berikut:

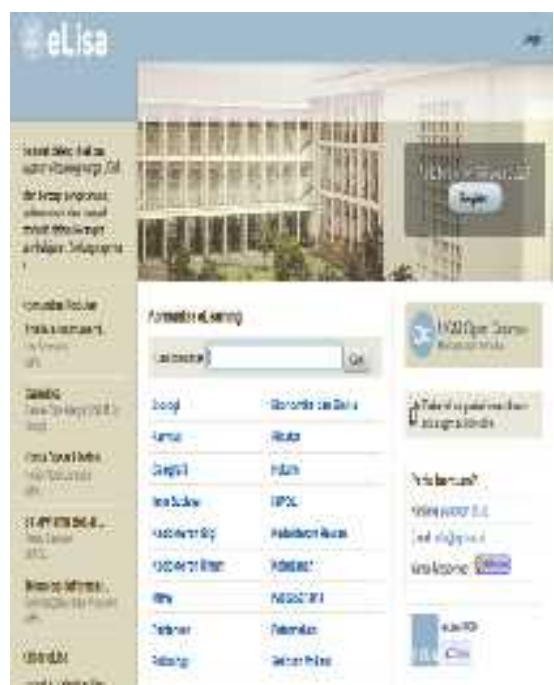

Gambar 3. Tampilan Halaman Utama ElisaUGM

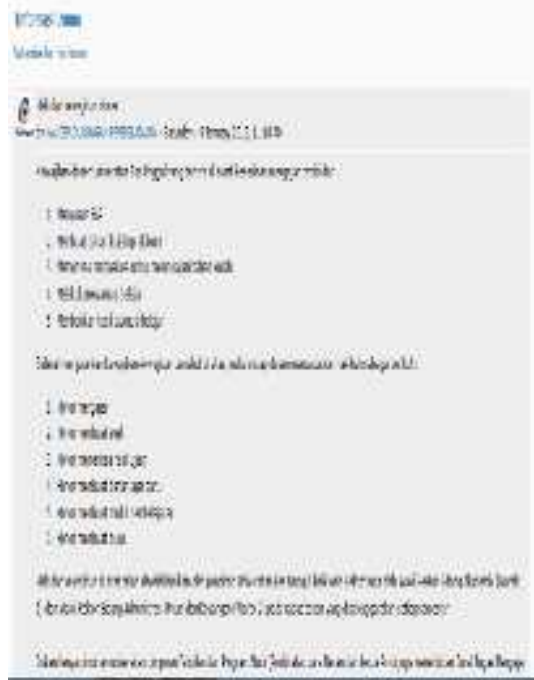

Gambar 4. Tampilan Halaman Utama e-Learning Universitas Esa Unggul

Berdasarkan Santoso ${ }^{26} \quad$ Untuk menyediakan sistem e-Learning dalam suatu organisasi, katakanlah institusi pendidikan, 
terdapat beberapa pilihan, diantaranya adalah:

1. Mengembangkansendiri,

Artinyainstitusiperlumemiliki tim untuk pengembangan sistem.

Pilihanmetodologipengembangandan

teknologi yang akan digunakan

merupakan 'hak prerogratif' tim

pengembang dengan memperhatikan pertimbangan-pertimbangan yang ada.

2. Membelisistem yang sudah ada.

Salah satu hal yang bisa digunakan untuk menebak mengapa suatu organisasi membeli aplikasi perangkat lunak atau perangkat keras adalah tersedianya anggaran yang dimiliki serta berbagai pertimbangan seperti kemudahan, khususnya pendeknya waktu implementasi serta layanan pascaimplementasi. Namun yang perlu diperhatikan dari pilihan ini adalah seringkali fasilitas yang ada terlalu kompleks dari apa sebenarnya yang dibutuhkan organisasi yang bersangkutan.

3. Menggunakan open source e-Learning system.

Saat ini telah terdapat beberapa sistem eLearning berbasis open source seperti Moodle, Claroline, dan yang lainnya. Jelas, bagi organisasi yang akan memanfaatkan software ini tidak perlu membayar.

4. Melakukankustomisasi.

Melakukan kustomisasi artinya memanfatkan kembali modul-modul yang tersedia, baik itu dikembangkan sendiri, dari software open source ataupun dengan cara membeli dengan tujuan untuk dapat dimodifikasi sesuai requirements yang dibutuhkan organisasi.

\section{HASIL dan PEMBAHASAN}

Analisis dan Perancangan Aplikasi Terminologi dan Klasifikasi Penyakit (ICD-10)

Prototipe AplikasiTerminologi Medis dan Klasifikasi Penyakit telah dikembangkan oleh Prodi D3 Rekam Medis $\mathrm{UGM}^{14}$ dengan menggunakan database MySQL dan bahasa pemrograman PHP yang berbasis web yang memungkinkan informasi dapat diakses dan program ini dapat dibuka dengan menggunakan aplikasi browser seperti internet explorer, opera dan mozilla firefox. PHP yang digunakan versi 5 sebagai serverside scripting, XHTML1.0 untuk mengatur user interface, CSS (Cascading Style Sheet) untuk mengatur layout tampilan, JavaScript sebagai client-side scripting, dan JQuery, sebagai framework untuk membantu penggunaan AJAX (Asynchronous JavaScript and $X M L$ ) yaitu teknik dalam JavaScript untuk melakukan panggilan ke server.

Administrator dalam aplikasi ini dapat terdiri dari Administrator (pengelola) aplikasi, dosen ataupun mahasiswa yang sebelumnya sudah terdaftar sebagai Administrator. Sedangkan user dapat terdiri dari mahasiswa dan dibatasi hak aksesnya hanya untuk melihat informasi tanpa ada wewenang merubah isi aplikasi. Administrator dan user harus login terlebih dahulu ketika masuk pertama kali pada aplikasi. Aplikasi akan memproses melalui 
nama dan password yang telah tersimpan dalam database sistem. Wewenang dosen dan mahasiswa sebagai Administrator adalah keleluasaan untuk merubah, menambah serta menghapus isi informasi dalam aplikasi, baik materi maupun soal latihan serta nilai akhir.

\section{User Interface}

Gambaran secara garis besar dari aplikasi tersebut dapat dijelaskan sebagai berikut:

1) Tampilan Antar Muka Aplikasi

Setelah berhasil login, maka dosen dan mahasiswa akan dihadapkan pada tampilan antar muka sebagaimana yang ditunjukkan dibawah ini.
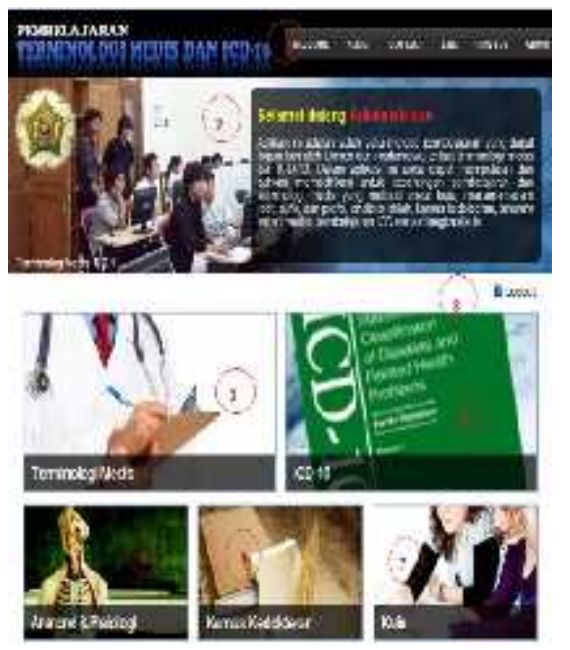

Gambar 5. Tampilan Antar Muka

Keterangan:

1.Tool Bar

2.Notification Box

3.Modul Terminologi Medis

4.Modul ICD-10

5.Modul Anatomi dan Fisiologi

6.Modul Kamus Kedokteran

7.Kuis

8.Logout

2) Melihat dan Memahami Aplikasi

Pada bagian body atau content terdapat enam blok modul, dengan Terminologi Medis dan ICD-10 sebagai modul utama yang tampak dengan ukuran blok yang lebih besar. Modul yang lain adalah Modul Anatomi \& Fisiologi, Kamus Kedokteran, dan Kuis.

a) Modul terminologi Medis dan Modul Anatomi Fisiologi

Tampilan modul terminologi medis dan modul anatomi fisiologi dapat di lihat pada gambar 6 di bawah ini:

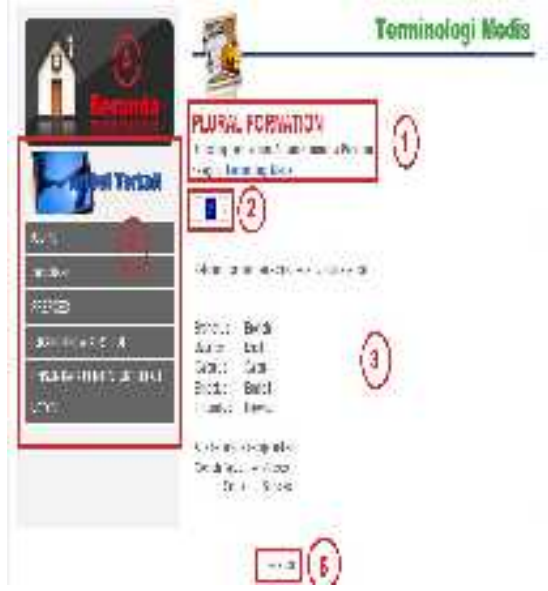

Gambar 6. Tampilan Modul Terminologi Medis

Keterangan:

1.Informasi tentang artikel

2.Halaman slide artikel

3.Halaman artikel

4.Artikel terkait

5.Beranda, menuju ke menu utama

b) Modul ICD-10

Modul ICD-10 berisi informasi terkait pembelajaran ICD. Modul ini dapat dikembangkan lagi berdasarkan pada kekhususan materi yang disesuaikan tingkat semester mahasiswa D3 Rekam MedisUGM.Sebagai gambaran tampilannya, dapat di lihat pada gambar7. 


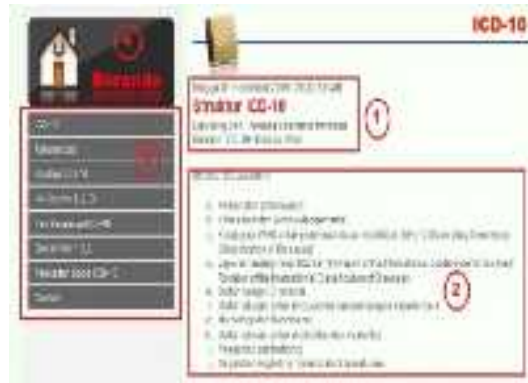

Gambar 7. Tampilan Modul ICD-10

Keterangan:

1.Informasi tentang artikel

2.Halaman artikel

3.Artikel terkait

4.Beranda, menuju ke menu utama

c) Modul Kamus Kedokteran

Modul KamusKedokteran terdiri dari fasilitas untuk melakukan pencarian istilah dalam kamus kedokteran dan sinonim dari istilah terkait secara elektronik yang dilengkapi dengan fasilitas auto suggestion.

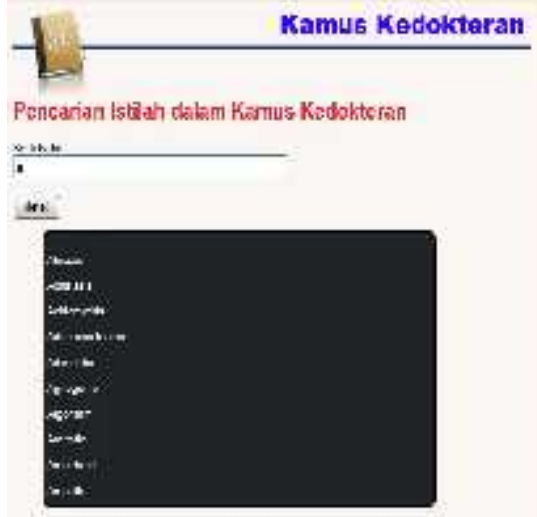

Gambar 8. Tampilan Kamus Kedokteran

d) Modul Kuis

Modul Kuis terdiri dari kuis pilihan ganda, terminologi medis dan ICD-10:

i) KuisPilihanGanda

Berisi kuis dengan bentuk soal pilihan ganda. Peserta kuis diberi waktu 10 menit untuk mengerjakan 10 soal. Secara otomatis nama dari user akan tercatat pada halaman top skor setelah mengikuti kuis ini.

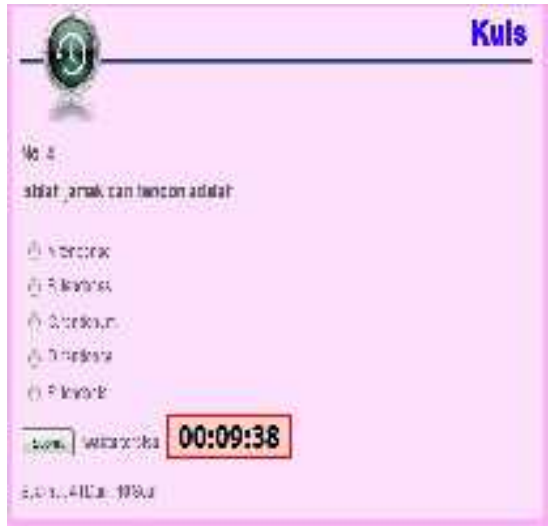

Gambar 9. Tampilan Kuis pilihan ganda

ii) KuisTerminologiMedis

Berisi kuis tentang terminologi medis dengan bentuk soal isian singkat. Secara otomatis nama dari user akan tercatat pada halaman top skor setelah mengikuti kuis ini.

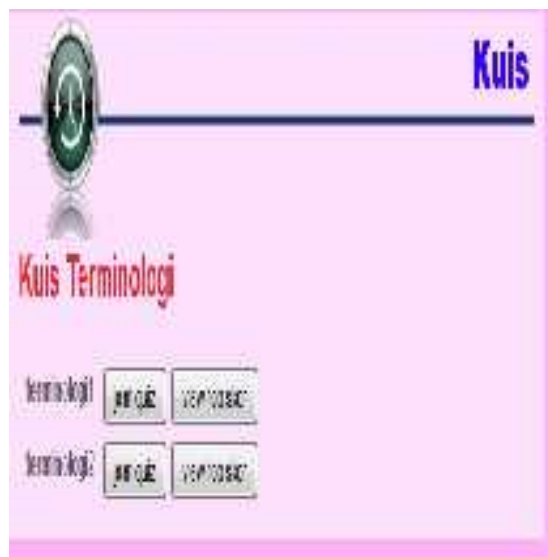

Gambar 10. Tampilan Kuis Terminologi

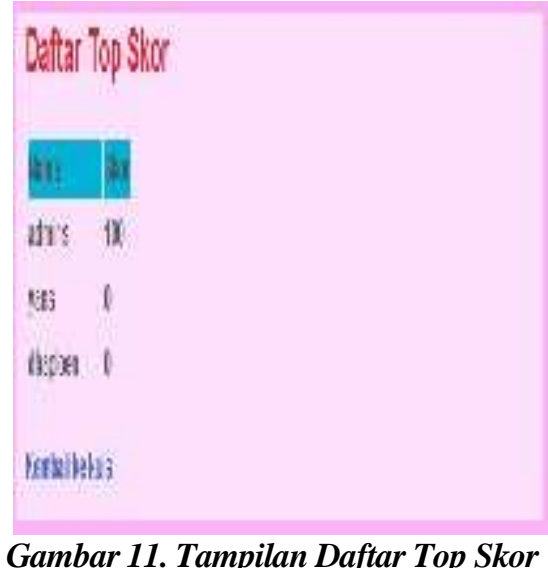

Gambar 11. Tampilan Daftar Top Skor 
Aplikasi ini menyediakan menu home dan menu administrator. Menu home disediakan hanya untuk menggunakan aplikasi tanpa merubah isi materi. Untuk perubahan isi materi disediakan pada menu administrator.

Halaman administrator dapat diakses dengan meng-klik menu ADMIN pada menu bar bagian kanan atas. Tidak semua pengguna dapat dengan leluasa merubah isi materi aplikasi, pengguna akan diberikan hak akses tertentu. Hanya admin yag diberikan hak kuasa penuh dalam modifikasi materi aplikasi. Halaman administrator terdiri dari menu:

1) Home

Saat pertama kali mengakses halaman administrator maka otomatis akan masuk ke menu home dari administrator

2) Manajemen User

Berisimoduluntukmanajemen user baikitumenambah, mengeditmaupunmenghapus user

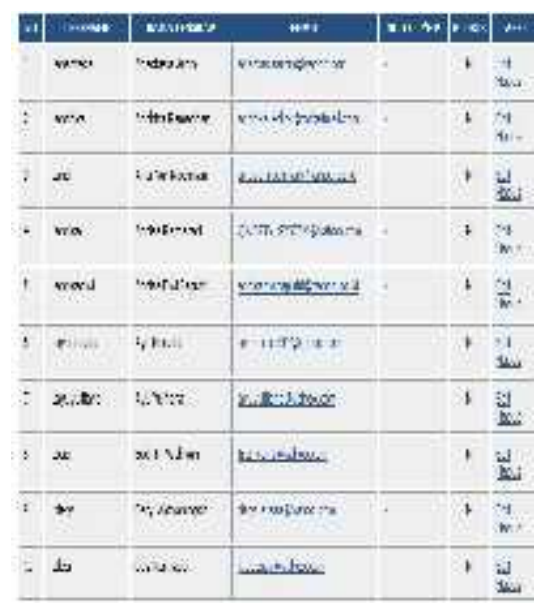

Gambar 12. Tampilan Menu Administrator
3) ManajemenModul

Berisimoduluntukmanajemenmodulbaikitu menambah,mengeditmaupunmenghapusmo dul

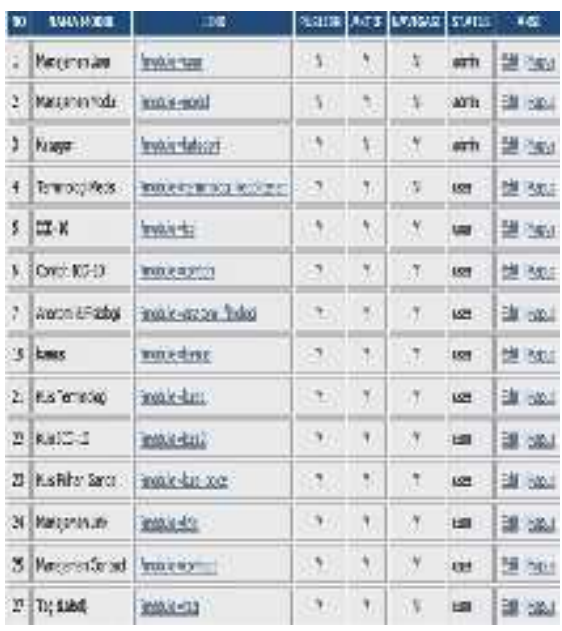

Gambar 13. Tampilan Tambah Menu

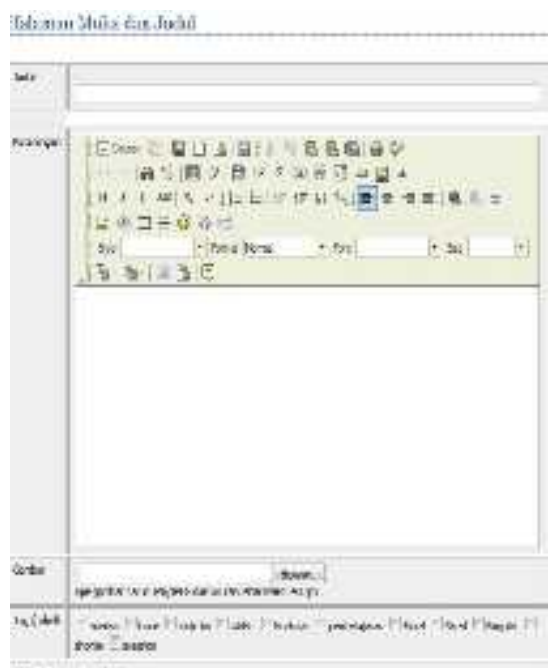

\section{anm as}

Gambar 14. Tampilan Menu

Administrator Menambah Materi

4) Contoh ICD-10

Berisimoduluntukmenambah,mengeditmau punmenghapuscontohpenggunaan ICD-10 dalampencariankode diagnosis. 


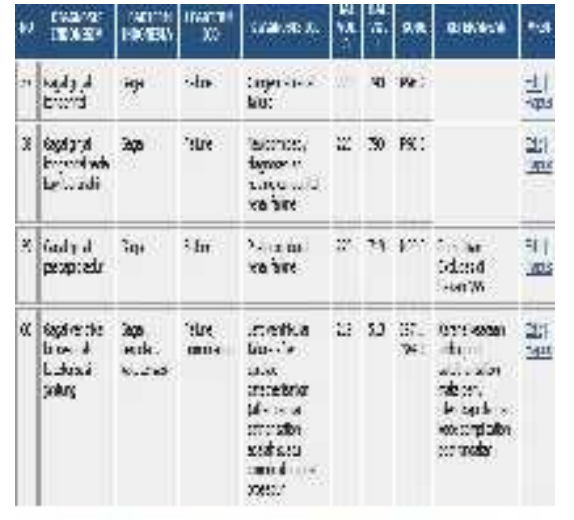

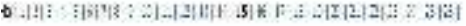

Gambar 15. Tampilan Menu

Administrator Pembelajaran ICD-10

5) Anatomi\&Fisiologi

Berisi modul untuk menambah, mengedit maupun menghapus artikel tentang anatomi dan fisiologi.

Arahisui 2 Frabigi

meenter

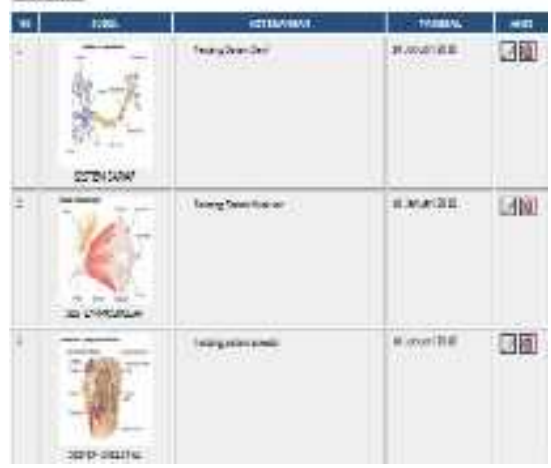

Gambar 16. Tampilan Menu

Administrator Anatomi dan Fisiologi

6) Kamus

Berisimoduluntukmanajemen

databasekamuskedokteranbaikitumenamba $\mathrm{h}$, mengeditmaupunmenghapus recordistilahdalamkamuskedokteran.

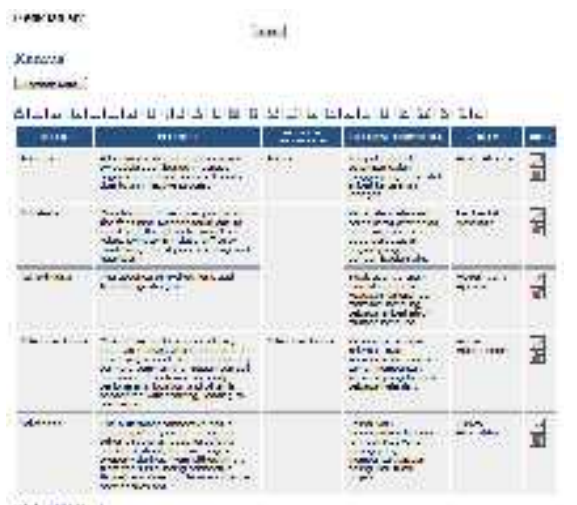

Gambar 17. Tampilan Menu

Administrator Kamus Kedokteran

7) KuisTerminologiMedis

Berisi modul untuk menambah, mengedit maupun menghapus kategori, soal dan jawaban dalam kuis terminologi medis.

\section{Kuis Terminologi}

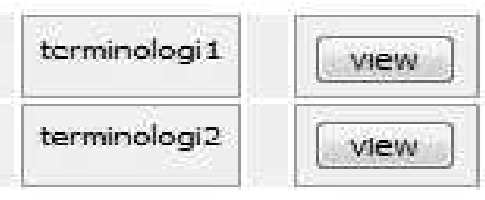

\section{Manajemen Kategori \\ Gambar 18. Tampilan Menu \\ AdministratorKuisTerminologi}

\section{Manjemen Soal}

\section{Tambah Soal}

\begin{tabular}{|c|c|c|}
\hline SUAL & SAWABAN & AKSI \\
\hline gaster & lambung & Edit I Hapus \\
\hline renal & ginjal & Edit I Hapus \\
\hline liven & Iirali & Filit I Hatris \\
\hline dactyl & jari & Edit I Hapue \\
\hline cardio & jantung & Edit I Llepus \\
\hline stomato & mulut & Edit | Hapus \\
\hline pulmo & Daru-paru & Edit I Llapus \\
\hline
\end{tabular}

Administrator Manajemen Soal 


\section{HASIL UJI COBA}

Tahap uji coba aplikasi terminologi medis dan klasifikasi penyakit (ICD-10) dilakukan dengan dua cara, yaitu melalui kuesioner kemudahan dan kemanfaatan dan diskusi kelompok terfokus (FGD). Implementasi Aplikasi Terminologi Medis \& Klasifikasi Penyakit (ICD-10) dilakukan melalui ujicoba program kepada mahasiswa semester I, III, dan V Program Studi D3 Rekam Medis Universitas Gadjah Mada Yogyakarta yang berjumlah 120 orang $^{14}$. Proses implementasi diawali dengan penjelasan secara rinci penggunaan Aplikasi Terminologi Medis \& Klasifikasi Penyakit (ICD-10) ini kepada mahasiswa oleh peneliti. Setelah program ini digunakan maka mahasiswa menjawab pertanyaan dari kuesioner yang telah disiapkan peneliti dan hasil dari kuesioner tersebut selanjutnya dianalisis yang akan dijelaskan di bawah ini.

a. Karakteristik responden.

Karakteristik responden pada penelitian ini meliputi umur, jenis kelamin, tingkat semester, waktu pertama kali belajar komputer, frekuensi penggunaan komputer, kepemilikan komputer atau leptop di rumah, dan kemampuan dalam penguasaan komputer.

1) Distribusi umur responden Distribusi umur responden pada penelitian ini berkisar antara 1742tahun dengan rata-rata 19, 98 tahun. Umur paling muda adalah 17 tahun dan yang paling tua adalah 42 tahun.
Tabel 1.Distribusi Umur Responden

\begin{tabular}{|l|c|}
\hline \multicolumn{1}{|c|}{ Faktor } & Nilai \\
\hline Mean & 19,98 \\
Median & 19 \\
Minimum & 19 \\
Minimum & 17 \\
Maximum & 17 \\
\hline
\end{tabular}

Frekuensi umur dari responden paling banyak pada umur 17-19 tahun yaitu sebesar 70 orang. Kemudian jumlah mahasiswa umur 2030 tahun sebesar 46 orang. Selain itu terdapat mahasiswa yang berumur lebih dari 30 tahun berjumlah 4 orang. Hal ini dikarenakan mahasiswa tersebut adalah tugas belajar dari instansi tempat bekerja mereka masing-masing. Responden terbanyak berumur 17-19 tahun, hal ini dikarenakan mahasiswa semester satu dan tiga rata-rata berumur 17-19 tahun. Untuk lebih jelas dapat dilihat pada tabel 2 di bawah ini.

Tabel 2.Frekuensi Umur Responden

\begin{tabular}{|c|c|c|}
\hline Umur & Frequency & Percent \\
\hline $17-19$ & 70 & 58,3 \\
\hline $20-30$ & 46 & 38,3 \\
\hline $31-42$ & 4 & 3,3 \\
\hline Total & 120 & 100 \\
\hline
\end{tabular}

Di bawah ini dicantumkan gambar diagram dari frekuensi umur responden. 


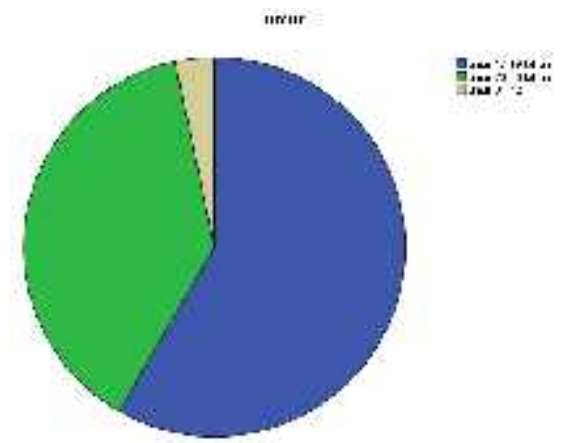

responden $(41,7 \%)$ semester III, dan 30 responden $(25 \%)$ semester $\mathrm{V}$.

Gambar 20. Frekuensi Umur Responden

2) Distribusi jenis kelamin responden Jenis kelamin perempuan lebih banyak dibandingkan dengan laki-laki, yaitu berjumlah 92 orang $(76,7 \%)$ dari 120 responden.

Tabel 3. Distribusi Responden Berdasarkan Jenis Kelamin

\begin{tabular}{|l|c|c|}
\hline $\begin{array}{l}\text { Jenis } \\
\text { Kelamin }\end{array}$ & Frequency & Percent \\
\hline laki-laki & 28 & 23,3 \\
\hline Perempuan & 92 & 76,7 \\
\hline Total & 120 & 100 \\
\hline
\end{tabular}

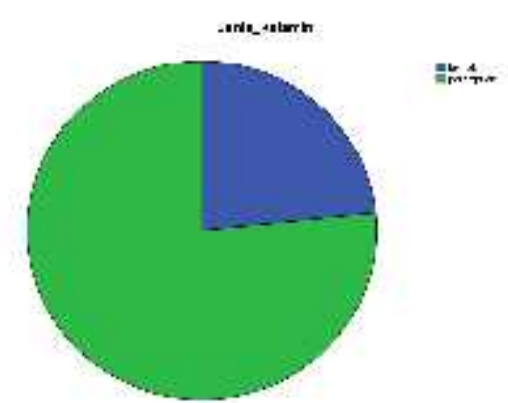

\section{Gambar 21. Karakteristik Responden} Berdasarkan Jenis Kelamin

3) Distribusi responden terkait tingkat semester

Distribusi responden berdasarkan tingkat semester terlihat bahwa dari 120 responden ada sebanyak 40 responden $(33,3 \%)$ semester I, 50 
Tabel 4.Distribusi Responden Berdasarkan TingkatSemester

\begin{tabular}{|l|c|c|}
\hline \multicolumn{1}{|c|}{ Semester } & Frequency & Percent \\
\hline semester I & 40 & 33,3 \\
\hline semester III & 50 & 41,7 \\
\hline semester V & 30 & 25 \\
\hline Total & 120 & 100 \\
\hline
\end{tabular}

4) Distribusi responden terkait kepemilikan komputer dan frekuensi penggunaan komputer

Distribusi responden yang memiliki komputer atau leptop di rumah, serta frekuensi penggunaan komputer dalam satu minggu dapat di lihat pada tabel 5 dan 6 di bawah ini.

Tabel 5.Kepemilikan Komputer Respoden

\begin{tabular}{|l|c|c|}
\hline \multicolumn{1}{|c|}{ Kepemilikan } & Frequency & Percent \\
\hline Memiliki & 108 & 90 \\
\hline Tidak memiliki & 12 & 10 \\
\hline Total & 120 & 100 \\
\hline
\end{tabular}

Tabel 6.Frekuensipenggunaan komputer

\begin{tabular}{|l|c|c|}
\hline \multicolumn{1}{|c|}{ Penggunaan } & Frequency & Percent \\
\hline 1-3 kali/minggu & 42 & 35 \\
\hline $4-5$ kali/minggu & 11 & 9,2 \\
\hline $\begin{array}{l}\text { Lebih dari 5 kali/ } \\
\text { minggu }\end{array}$ & 67 & 55,8 \\
\hline Total & 120 & 100 \\
\hline
\end{tabular}

Pada tabel di atas, jumlah responden yang memiliki komputer di rumah berjumlah 108 responden (90\%) dan 67 responden $(55,8 \%)$ lebih dari lima kali menggunakan komputer dalam satu minggu. Dengan demikian kemampuan responden dalam penggunaan komputer cukup tinggi.

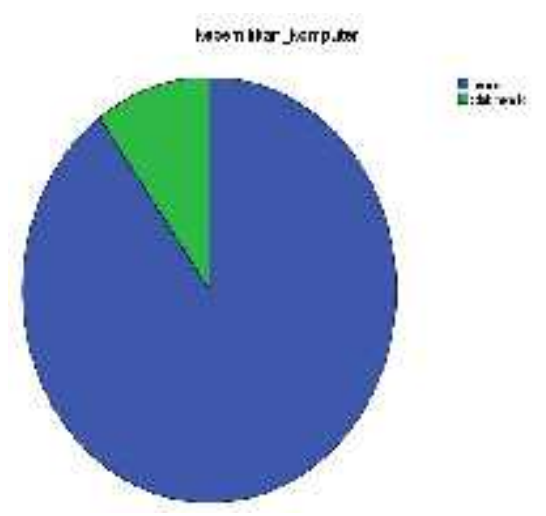

\section{Gambar 22. Karakteristik Responden} Berdasarkan Kepemilikan Komputer

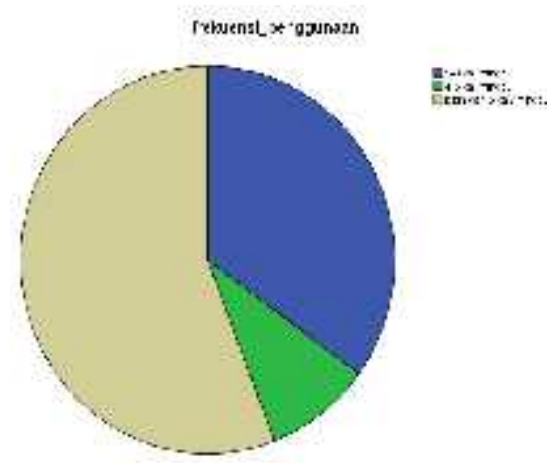

\section{Gambar 23. Karakteristik Responden Berdasarkan Frekuensi penggunaan komputer dalam 1 minggu}

5) Distribusi responden tentang kemampuan dalam menggunakan komputer.

Distribusi dari responden berdasarkan kemampuan dalam menggunakan komputer adalah $100 \%$ semua responden mampu 
mengunakan aplikasi Microsoft Word, 79,2\% mampu Microsoft Excel, 40,8\% mampu Microsoft Access, dan masih banyak juga responden yang mencantumkan kemampuan dalam penggunaan program Microsoft Power Point, Epi Info, Autocad, Photoshop maupun yang lainnya. Dengan demikian kemampuan responden untuk menggunakan komputer sangat tinggi. Untuk lebih jelasnya dapat dilihat pada tabel 7 di bawah ini.

Tabel 7.Distribusi responden berdasarkan kemampuandalam menggunakan program komputer

\begin{tabular}{|l|l|c|c|}
\hline Program & Kemampuan & Frequency & Percent \\
\hline MS Word & $\begin{array}{l}\text { keterangan } \\
\text { kampu/tanpa }\end{array}$ & 25 & 20,8 \\
\hline MS Excel & $\begin{array}{l}\text { tidak } \\
\text { Mampu }\end{array}$ & 95 & 79,2 \\
\hline $\begin{array}{l}\text { Total } \\
\text { Access }\end{array}$ & $\begin{array}{l}\text { tidak mampu/ } \\
\text { kanpa } \\
\text { keterangan }\end{array}$ & 71 & 100 \\
\hline Mampu & 49 & 40,8 \\
\hline & Total & 120 & 100 \\
\hline
\end{tabular}

b. Persepsi kemanfaatan dan kemudahan aplikasi Terminologi Medis dan Klasifikasi Penyakit (ICD-10).

Pada penelitian ini ada 2 (tiga) hal penting yang diukur dari akhir ujicoba penggunaan program ini meliputi kemudahan, dan kemanfaatan dan melalui diskusi kelompok terfokus. Evaluasi kemudahan dan kemanfaatan dengan menggunakan kuesioner yang diadopsi dari penelitian Davis ${ }^{7}$ dengan Skala Alpha Cronbach's sebesar 0,98 untuk kemanfaatan (perceived usefulness) dan 0,94 untuk persepsi kemudahan (perceived ease of use). Modifikasi 16 pertanyaan dalam Bahasa Indonesia yang digunakan sebagai kuesioner dalam penelitian ini dapat dilihat pada lampiran.

Analisis hasil kuesioner dilakukan secara bivariat dengan menggunakan analisis One Way Anova dan Post Hoc Test dengan tingkat kepercayaan $95 \%$.

Berdasarkan tabel 8, dapat dibuktikan bahwa persepsi kemanfaatan berdasarkan umur, kemampuan komputer, kepemilikan komputer memiliki hasil $\mathrm{F}$ hitung yang lebih besar ( $\mathrm{F}$ hitung umur 0,773; F hitung kemampuan komputer 1,954; F hitung kepemilikan komputer 0,658 ) dibandingkan dengan $\mathrm{F}$ teori yaitu lebih besar dari 0,05, maka dapat dibuktikan bahwa tidak ada perbedaan secara signifikan antara persepsi kemudahan dengan umur, kemampuan komputer, dan kepemilikan komputer. Nilai terendah dari karakteristik umur, kemampuan komputer dan kepemilikan komputer adalah 3, 63 dan tertinggi adalah 5 dengan data homogenitasnya sebesar lebih besar dari 0,05 maka data tersebut adalah homogen. Dikarenakan hasil analisis tidak menunjukkan perbedaan yang signifikan, maka tidak dilanjutkan dengan analisis Post Hoc Test. Akan tetapi persepsi kemanfaatan jika dibandingkan dengan jenis kelamin 
mempunyai pengaruh yang signifikan, hal ini dapat dibuktikan dari hasil $F$ hitungnya sebesar 0,014 yang lebih rendah dari $\mathrm{F}$ teori $(0,05)$.

Hasil analisis secara statistik menghasilkan informasi seperti yang tercantum dalam tabel 8 , dapat dibuktikan bahwa persepsi kemudahan jika dibandingkan dengan tingkat semester, umur, kemampuan komputer dan kepemilikan komputer diperoleh nilai terendah adalah 2,75 dan tertinggi adalah 4,88 dengan data homogenitasnya lebih besar dari 0,05 maka data tersebut adalah homogen. Sedangkan hasil dari F hitung sebesar 2,718 untuk tingkat semester, 1,914 untuk umur, 0,993 untuk kemampuan komputer dan 1,652 untuk kepemilikan komputer lebih besar dari $\mathrm{F}$ teori 0,05 , maka dapat dibuktikan bahwa tidak ada perbedaan secara signifikan antara persepsi kemudahan dengan tingkat semester, umur kemampuan dan kepemilikan komputer dari responden. Dikarenakan hasil analisis tidak menunjukkan perbedaan yang signifikan, maka tidak dilanjutkan dengan analisis Post Hoc Test.

Tabel 8.Analisis Persepsi Kemanfaatan dan Kemudahan berdasarkan Analisis One way Anova

\begin{tabular}{|c|c|c|c|}
\hline $\begin{array}{c}\text { Karakteristik } \\
\text { Responden }\end{array}$ & Hipotesis & $\begin{array}{c}\mathrm{F} \\
\text { Hitung }\end{array}$ & $\begin{array}{l}\text { Perbedaan } \\
\text { Signifikan }\end{array}$ \\
\hline Persepsi Kem & aatan & & \\
\hline
\end{tabular}

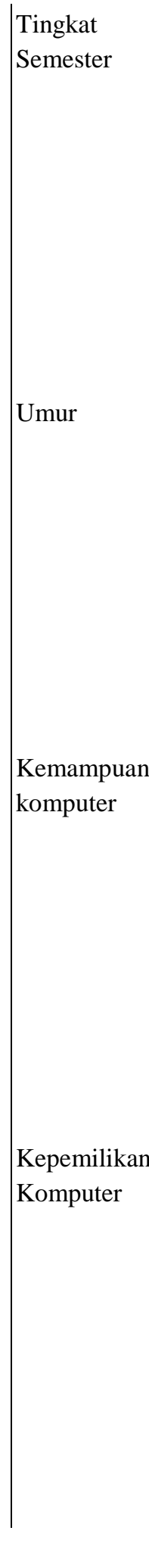

Ada

perbedaan

secara

signifikan

antara

persepsi

kemanfaatan

$1.797 \mathrm{Tdk}$

berdasarkan

tingkat

semester

Ada

perbedaan

secara

signifikan

antara

$\mathrm{Tdk}$

persepsi

kemanfaatan

berdasarkan

umur

Ada

perbedaan

secara

signifikan

antara

persepsi

kemanfaatan

$1.954 \mathrm{Tdk}$

berdasarkan

kemampuan

komputer

Ada

perbedaan

secara

signifikan

antara

persepsi

kemanfaatan

$.658 \mathrm{Tdk}$

kepemilikan

komputer 


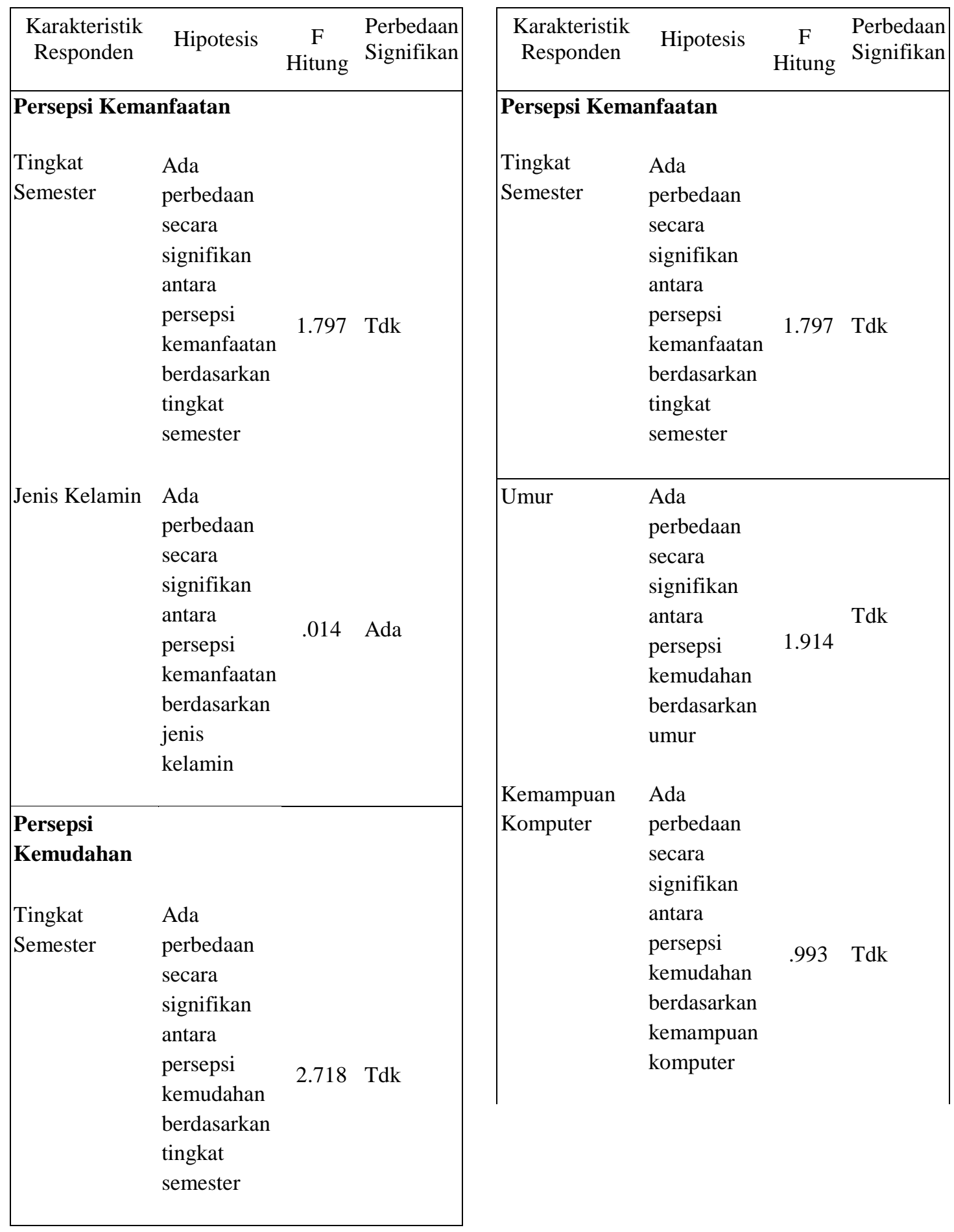




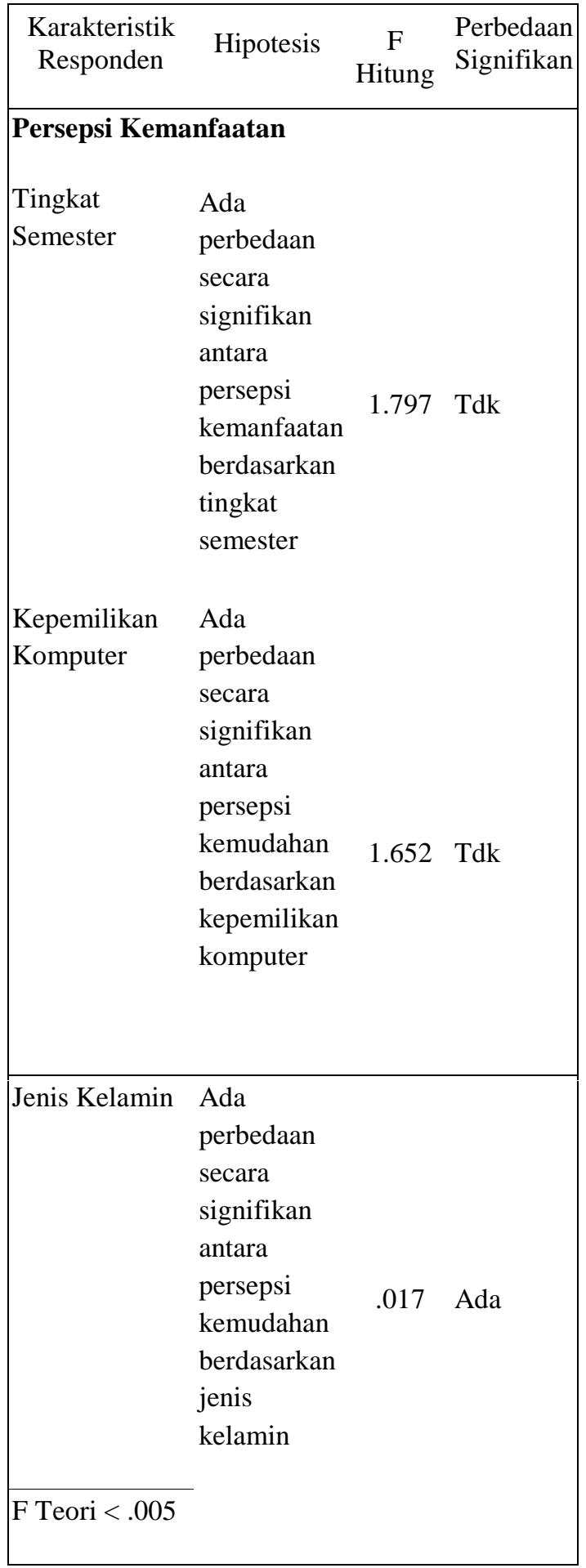

Selain dari hasil kuesioner yang menyatakan responden setuju jika aplikasi ini bermanfaat dan mudah digunakan, juga dari hasil diskusi kelompok terfokus menyatakan bahwa aplikasi ini bermanfaat, seperti hasil kutipan di bawah ini:

"Ya, dengan adanya penerapan aplikasi ini sangat bermanfaat untuk meningkatkan pemahaman dan pegetahuan akan matakuliah ilmu penyakit \& laboratorium kesehatan”. Responden 6

"Dapat, dengan program ini saya yakin akan bermanfaat untuk pemahaman dan pengetahuan saya”.Responden 1, 7, 9

"Bisa untuk menambah belajar di luar kelas, biar tambah paham dan tidak ketinggalan dengan teman yang lain”. Responden 8, 10

"Ya, karena dapat lebih membantu dalam memahami matakuliah IPLK yang sebagian besar referensinya bahasa inggris”. Responden 4

"sangat bermanfaat, bisa untuk mereview materi, karena semester $V$ sudah tidak ada kuliah IPLK". Responden 3, 2, 5

"Memang kapan aplikasi ini mau kita gunakan? Saya pikir kalo sudah digunakan akan lebih bermanfaat jika data dilengkapi”. Responden 6

"Kalau saya bingung karena belum dapat matakulliah ICD-10, apalagi kuisnya susah-susah”. Responden 8

"Saya masih semester I yang saya bisa lakukan dengan program ini hanya terminologi medis. Karena kebetulan saya sedang pelajari dalam semester ini”. Responden 10

"Kalau bisa kuis dikelompokkan, jangan dijadikan satu dengan ICD10, kan kita belum dapat materinya”. Responden 9 


\begin{abstract}
"enak
kok

$b u$

(mudah)". Responden 2

"Program ini cukup mudah karena di dalamnya tidak terdapat prosedur yang rumit dan membingungkan. Juga difasilitasi dengan bahasa yang mudah

dipahami”. Responden 1

"mudah kok bu, aku yang kayak gini aja bisa, apalagi yang lain”. Responden 6

"Ya mudah karena tinggal pilih menu kemudian klik langsung deh ada datanya sesuai yang kita inginkan”. Responden 3, 8

“Cukup mudah karena perintahnya mudah dipahami, praktis, sangat sederhana dalam mengoperasikannya terutama untuk pembelajaran”. Responden 7,9,10
\end{abstract}

Menurut Kendall \& Kendall $^{30}$ bahwa prototipe awal dapat kurang lengkap sehingga perlu diupayakan pengembangan prototipe menjadi lebih sempurna dan ini dapat dilakukan karena fleksibilitas dari perangkat lunak yang digunakan dalam aplikasiini memungkinkan untuk dilakukan penambahan ataupun pengurangan dari menu-menu yang ada pada prototipe aplikasi terminologi medis \& ICD-10 ini. Dalam aplikasi ini tersedia menu Admin yang mana dosen ataupun mahasiswa dapat melakukan penambahan atau pengurangan dari database.

Berdasarkan hasil wawancara dengan responden, terdapat jawaban responden yang menyatakan tidak setuju dan ragu-ragu bahwa aplikasi ini mudah digunakan, Hal ini disebabkan karena pemakaian aplikasi hanya satu kali, dan belum digunakan secara periodik. Jika dilihat dari tingkat semesternya, rata-rata mahasiswa yang merasa sedikit kesulitan dalam menjalankan aplikasi ini adalah semester I, dikarenakan baru mendapatkan materi terminologi medis, belum menempuh ICD-10. Hasil dari diskusi kelompok terfokus dapat dilihat dari kutipan responden di bawah ini:

”Agak sulit, mungkin karena baru sekali ini dikasih tau, kurang nyobanyoba”.Responden 7, 10

"Kalu aplikasi ini sudah mulai digunakan, aku yakin lebih mudah karena akan sering memakainya”. Responden 6

$\begin{array}{lccr}\text { "Agak bingung } & \text { karena } & \text { belum } \\ \text { pernah dapat } & \text { materi } & \text { ICD- } \\ \text { 10". Responden } 8 & & \end{array}$

Kelebihan prototipe terminologi medis dan ICD-10 yang digunakan sebagai bentuk dari teknologi informasi dan komunikasi adalah sebagai berikut:

a. Dapat mengurangi kelemahan pembelajaran konvensional, yang mana sumber belajar tergantung dari dosen, dilaksanakan sesuai jadwal, terbatas pada waktu dan kesempatan

b. Aplikasi ini dapat dengan mudah digunakan oleh banyak mahasiswa walaupun waktu yang bersamaan, yaitu dapat digunakan dengan bantuan jaringan yang terhubung dalam sebuah server. Selain itu, aplikasi ini dapat digunakan secara individual pada sebuah komputer atau leptop. 
c. Real time; untuk top score (nilai hasil tes) dapat dilihat langsung setelah selesai mengerjakan tes, jika terhubung secara jaringan maka nilai adalah yang 10 besar yang dapat ditampilkan. Materi dan soal serta jawaban juga dapat diubah serta dapat dilihat secara langsung hasil editnya. Bukti real time yang lain adalah manajemen user dan manajemen modul untuk menambah, mengurangi secara langsung user dan materi pembelajaran.

d. Update; materi dan soal dapat diupdate setiap saat melalui manajemen modul. Pengguna juga dapat ditambah atau dikurangi melalui manajemen user. Sehingga materi, soal maupun user dapat langsung terupdate.

e. Sistem ini diterima oleh mahasiswa D3 Rekam Medis UGM, hal ini dibuktikan dengan hasil rata-rata dari kemudahan dan kemanfaatan yang tinggi, yaitu sebesar 4,15 untuk kemudahan dan 4,32 untuk kemanfaatan.

f. Proporsi pengguna komputer banyak, yakni $55,8 \%$ responden menggunakan komputer lebih dari lima kali serta 90\% memiliki komputer atau leptop pribadi

g. Sumber belajar tambahan yang berisi materi dan latihan-latihan terkait terminologi medis dan klasifikasi penyakit (ICD-10). Yang mana latihan menurut Pribadi ${ }^{3}$ dapat memperbaiki daya ingat serta memperbaiki kemampuan mahasiswa untuk mengaplikasikan pengetahuan dan ketrampilan yang baru dipelajari. Hal ini didukung oleh Bryner, et $a l .{ }^{31}$ menyatakan bahwa penggunaan modul yang berisi pembelajaran interaktif berupa kuis sangat membantu saat belajar tentang konsep. Mahasiswa dapat memahami pembelajaran dengan menggunakan kuis.

Masrom $^{22}$ menyatakan bahwa Elearning tidak untuk menggantikan pembelajaran di kelas tetapi merupakan peluang untuk berinteraksi dan berkomunikasi antara dosen dan mahasiswa. Hal senada juga disampaikan oleh Zebrack et al., ${ }^{4}$; Stern et al., ${ }^{5}$; Gold et al., ${ }^{6}$ bahwa aplikasi dengan bantuan komputer merupakan salah satu alat bantu dalam pembelajaran yang dapat meningkatkan pengetahuan, keterampilan serta merupakan salah satu metode yang efektif. Metode pembelajaran dengan pendekatan elearning merupakan salah satu metode pembelajaran berpusat mahasiswa (student centered learning) (Harsono \& Dwiyanto $^{23}$ ). Manfaat dari aplikasi dengan bantuan komputer dan elearning adalah dapat meningkatkan kesenjangan antara pengajar dan peserta didik, dapat menjadi alat simulasi pemecahan masalah melalui studi kasus dan latihan yang didesain secara interaktif (Zebrack et al.. ${ }^{4}$; Mc Kimm et $\left.a l .,{ }^{24}\right)$. Selain itu konsep pembelajaran $e$ learning merupakan alternatif pembelajaran yang lebih efektif dan efisien dan merupakan konsep distance learning (Sa'ud, ${ }^{20}$, Sanjaya $\&$ Leong $^{25}$ ). Konsep pembelajaran interaktif salah satunya adalah dilengkapi dengan latihan. Latihan dalam suatu aplikasi salah satunya adalah dalam bentuk kuis, kuis menurut Harsono \&Dwiyanto ${ }^{23}$ merupakan teknik yang dapat mendorong partisipasi 
mahasiswa dalam pembelajaran aktif. Selain itu kuis atau ujian merupakan media untuk mengevaluasi hasil pembelajaran masingmasing peserta didik (Sanjaya \& Leong ${ }^{25}$ ).

Hal senada juga disampaikan oleh Whitten $^{32}$ dalam pengembangan suatu aplikasi dengan model prototipe dapat melalui langkah-langkah: identifikasi kebutuhan mendasar,membangun prototipe awal, implementasi prototipe, evaluasi kelengkapan, setelah lengkap kemudian prototipe dapat gunakan. Prototipe aplikasi terminologi medis dan ICD-10 dengan desain web disusun berdasarkan kerangka pikir bahwa aplikasi tersebut dapat digunakan untuk evaluasi keberhasilan pembelajaran serta dapat digunakan oleh seluruh mahasiswa D3 Rekam Medis, Dosen, petugas rekam medis di rumah sakit, maupun mahasiswa kedokteran dan keperawatan yang menginginkan pembelajaran terkait ICD-10. Aplikasi ini bersifat dinamis, yang mana user dapat menggunakan menu administrator untuk menambah, merubah, menghapus, membuat menu baru terkait menu yang ada di aplikasi. Hal ini senada dengan pendapat dari Harsono \& Dwiyanto $^{23}$ yang menyatakan bahwa pengetahuan merupakan proses dinamis yang berlangsung melalui proses terus-menerus dan memerlukan partisipasi aktif dari pembelajar.

Menurut Marentette, et $a l .{ }^{33}$ aplikasi interaktif dengan multimedia telah berkembang pesat dalam dunia pendidikan dan memungkinkan mencapai dan mencakup semua jenis pembelajar. Display interaktif dengan multimedia telah menciptakan layar lebar dengan kemampuan 3D display dan touch-screen. Virtual Field Trips memungkinkan siswa melakukan studi tur ke tempat-tempat yang jauh, bahkan mungkin yang tidak terjangkau, menjadi mudah untuk dikunjungi. Aplikasi untuk ini antara lain PhotoSynth, Virtual Earth, Google Earth. Untuk mempelajari anatomi tubuh manusia, persis seperti membedah langsung, digunakan Visible Human Project yang bisa digunakan untuk pembelajar tingkat SD hingga perguruan tinggi. Selain itu ada pula Games \& Learning, salah satunya adalah Dimenxian yaitu game 3D untuk belajar Aljabar dengan layar besar dan dapat diikuti oleh banyak pemain. Games atau permainan jenis ini sangat banyak, seperti Discovery Kids, Natural Geographic Kids, NASA for Kids, National Gallery of Art, EduSim $3 D$ yang kesemuanya merupakan multimedia pembelajaran interaktif. Hal senada juga disampaikan oleh Sabarguna \& Sungka $^{34}$ bahwa mengacu pada Learning Assisted System atau Computer Assisted Medical Education berarti penggunaan sistem informasi dan teknologi informasi serta komputer sudah banyak digunakan dalam dunia pendidikan kedokteran. Diantaranya adalah E-Book, simulasi yang menggunakan alat bantu dalam latihan dan praktek ekdokteran, Virtual Reality, Teleeducation dan telementoring yang mennguanakan metode pembelajaran jarak jauh. 
Contoh program interaktif yang lain adalah Hot potatoes, yaitu suatu software yang gratis dan dapat digunakan untuk pembelajaran dalam pembuatan kuis interaktif dalam format HTML. Kuis yang dibuat dapat dalam bentuk bahasa yang beragam, pengguna tinggal mengisi data, teks, pertanyaan, jawaban dan aplikasi akan membuatkan tampilannya. Model kuis yang disediakan antara lain model pilihan ganda, isian pendek, narasi, teka teki silang, pilihan atau urutan untuk menjodohkan. Aplikasi ini dapat diunduh melalui alamat http://www.hotpot.uvic.ca, tersedia versi untuk sistem operasi windows dan linux.

Perkembangan di Indonesia, dalam hal ini Universitas Gadjah Mada telah dikembangkan sistem elearning yang bernama eLIsa (elearning system for academic) (Kusminarto $\&$ Rahayuningsih ${ }^{35}$ ), sistem tersebut berbasis web yang dikembangkan oleh Unit Pengembangan Bahan Kuliah Berbasis Teknologi Informasi dan Komunikasi UGM serta dapat diakses secara umum melalui alamat http://elisa.ugm.ac.id dan http://ielisa.ugm.ac.id. Selain tingkat universitas, elearning juga dikembangkan oleh Fakultas Matematika \& Ilmu Pengetahuan Alam (MIPA) dengan nama Kuantum Gama (kuliah online untuk mahasiswa MIPA UGM) dengan alamat http://kuantum.mipa.ugm.ac.id dan Fakultas Teknik Elektro dengan nama Papirus yang dapat diakses melalui alamat http://papirus.te.ugm.ac.id, adapun bentuk lainnya diserahkan kepada masing-masing program studi atau unit/fakultas untuk mengembangkan sumber belajar elektronis ini. Akses untuk sumber belajar digital ini dibuka luas agar siapapun yang belajar, bila memiliki ketrampilan memperoleh sumber belajar dengan tepat, akurat dan valid, maka ia akan selalu terjaga dan up-to-date dalam bidang ilmu yang ditekuninya. Ketrampilan tersebut dapat muncul dengan memahami dasar-dasar keilmuan sesuai bidang yang dipilih, menguasai metode dalam bidang yang dipilih, memahami situasi dalam praktik bidang yang dipilih serta menguasai teknologi informasi dan komunikasi (Yohannes, et $a l .^{36}$ ). Sebagian besar dari sistem elearning tersebut menggunakan aplikasi Moodle yang dapat diperoleh secara open source. Selain menggunakan aplikasi Moodle, Fakultas Ilmu Komputer Universitas Indonesia menggunakan aplikasi secara open source juga dari articulate. Alamatnya dapat diakses melalui http://articulate.com. Jika dibandingkan dengan Moodle, Articulate lebih interaktif, karena menyediakan juga program untuk desain powerpoint, photoshop, dan kuis. Sofware ini dapat digunakan oleh semua orang untuk membuat secara cepat dan mudah sebuah kursus, presentasi, kuis yang diorganisasikan dalam bentuk elearning baik oleh seorang ahli, narasumber, instruktur pelatihan, guru, dosen maupun dosen tamu. Akan tetapi aplikasi ini mempunyai batas aktif selama 30 hari. Alasan aplikasi terminologi medis dan klasifikasi penyakit (ICD-10) didesain sendiri adalah menyesuaikan dengan 
kebutuhan, yaitu masih terbatas pada inovasi sistem pembelajaran yang bersifat spesifik, belum menyeluruh untuk aplikasi secara program studi. Akan tetapi tidak menutup kemungkinan bahwa aplikasi ini akan dikembangkan menjadi sebuah aplikasi yang lebih luas lagi untuk penggunaannya, sebagai contoh dapat dikembangkan sebagai pembelajaran elearning.

Aplikasi dengan metode elearning yang lain adalah dengan menggunakan website elearning dengan Atutor. Atutor ini merupakan salah satu perangkat lunak Learning Content Management System (LCMS), selain Atutor LCMS yang lain adalah Moodle, Sakai Project. Fasilitas yang disediakan adalah fasilitas forum, blog, chat, pembelajaran, bank pertanyaa, penilaian, dukungan multimedia, wiki, tugass kelompok, dan dukungan berbagai bahasa (Sanjaya \& Leong $^{25}$ ). Sofware ini dapat diperoleh secara gratis melalui alamat http://atutor.ca.

Aplikasi dengan metode elearning yang lain yang secara materi sangat mendukung aplikasi pada penelitian ini adalah aplikasi yang dikembangkan oleh WHO (World Health Organization) dengan nama ICD-10 Training. Aplikasi tersebut merupakan aplikasi baru yang dapat diakses secara umum, dengan alamat yang dapat diakses melalui

http://apps.who.int/classification/apps/icd/IC

D10Training. Dalam aplikasi ini dijelaskan secara detail kekhususan dari tiap bab dalam ICD-10 (bab I - XXII), selain itu dilengkapi dengan materi-materi yang terdapat pada volume 2 ICD-10 antara lain terkait informasi aturan tentang morbiditas dan mortalitas, serta bagaimana membuat sertifikat kematian. Aplikasi ini didesain cukup interaktif, yang mana materi dilengkapi dengan gambar dan kasus.

Persamaan dengan aplikasi pada penelitian ini adalah dengan menggunakan desain web dan digunakan sebagai alternatif alat pembelajaran. Perbedaannya jika pada sistem elearning yang ada di UGM didesain untuk keseluruhan matakuliah sedangkan aplikasi terminologi medis dan klasifikasi penyakit (ICD-10) khusus untuk matakuliah spesifik. Sedangkan perbedaan dengan aplikasi dari WHO adalah aplikasi terminologi medis dan klasifikasi penyakit (ICD-10) bersifat dinamis, yang mana pengguna dapat secara langsung melakukan modifikasi dalam rangka melengkapi materi dalam aplikasi, sedangkan aplikasi dari WHO bersifat statis, pengguna hanya dapat berinteraksi tanpa manipulasi materi.

Perangkat lunak (software) berfungsi mengatur jalannya suatu perangkat keras (hardware) agar dapat menampilkan sesuai dengan yang dibutuhkan. Secara umum software dibedakan menjadi 2 kategori, sistem (system) dan aplikasi (application) ${ }^{12}$. Perangkat lunak aplikasi merupakan langkah untuk mengembangkan program, baik programnya dikembangkan sendiri atau program yang sudah jadi $^{13}$. Program terminologi medis dan klasifikasi penyakit (ICD-10) yang peneliti rancang merupakan aplikasi berbasis web. Aplikasi berbasis 
Web memungkinkan pengguna untuk menggunakannya secara interaktif ${ }^{15}$. Pengguna dapat berkomunikasi dengan aplikasi secara interaktif tanpa batas dan waktu. Desain web mudah digunakan dan mudah dipahami, sehingga mudah dipelajari $^{16}$. Selain itu diperlukan adanya intervensi dari dosen pada aplikasi pembelajaran, hal ini dikarenakan intervensi pada proses pembelajaran memberikan efek yang berbeda. Intervensi tersebut dapat berupa sesuatu yang dapat digunakan, multimedia learning, sehingga proses belajar mengajar lebih efisien dan interaktif ${ }^{15}$. Instruksi belajar dengan bantuan komputer dengan suara, visual dan interaktifitas menjadikan multimedia sebagai pencipta lingkungan belajar interaktif yang meningkatkan intensitas proses belajarmengajar ${ }^{17}$. Sehingga pembelajaran dengan bantuan komputer merupakan strategi pembelajaran yang efektif dari segi biaya dan waktu.

Dalam perancangan media pembelajaran berbasis multimedia, digunakan konsep Multimedia Learning $^{18}$. Konsep ini menekankan pengembangan media pembelajaran interaktif berdasarkan metode learner-centered learning yaitu berpusat pada pembelajar atau mahasiswa. Contohnya dalam lingkungan belajar berbasis komputer, animasi bisa ditangkap secara visual, sedangkan narasi bisa ditangkap secara auditori. Sehingga multimedia dalam pembelajaran berfungsi sebagai konstruksi pengetahuan yaitu multimedia sebagai alat bantu kognitif.
Prototipe aplikasi terminologi medis dan klasifikasi penyakit (ICD-10) menggunakan desain web dengan tujuan agar mudah digunakan dan bermanfaat bagi mahasiswa. Konsep pembelajaran berbasis web dan dirancang sebagai metode elearning dapat memberikan pemahaman mahasiswa dan menjadikan mahasiswa akan terus menggunakan aplikasi dalam pembelajaran mereka $^{11,19}$. Prototipe aplikasi pada penelitian ini dikembangkan karena ada beberapa masalah dalam pembelajaran terminologi medis dan ICD-10 di D3 Rekam Medis UGM, antara lain matakuliah ICD-10 terdapat pada tiap semester; merupakan salah satu kompetensi utama petugas rekam medis (Permenkes 377 tahun 2007); terbatasnya pustaka dan tenaga pengajar yang profesional. Oleh karena itu aplikasi ini diharapkan dapat memberikan alternatif dalam pembelajaran ICD-10, dapat dikembangkan menjadi ebook (buku digital), sumber belajar serta media elearning. Pembelajaran harus didesain sesuai dengan kebutuhan dan karakteristik pengguna ${ }^{2}$. Oleh karena itu aplikasi ini dirancang untuk memenuhi kebutuhan mahasiswa D3 Rekam Medis UGM sebagai alat bantu dan tidak bermaksud untuk menggantikan perkuliahan metode konvensional (kelas) yang ada. Melalui informasi yang disajikan secara elektronik, alat-alat elektronik dapat dijadikan sumber informasi ${ }^{15}$ dan sebagai alternatif pencarian tambahan informasi dan sumber belajar yang diberikan dosen di kelas. 
Inovasi pendidikan adalah suatu perubahan yang baru yang berbeda dari sistem sebelumnya serta merupakan upaya yang disengaja untuk meningkatkan kemampuan guna mencapai tujuan dalam pendidikan yang lebih baik $^{20}$. Tujuan dari dilakukannya inovasi pembelajaran aplikasi terminologi medis dan ICD-10 adalah dapat menjangkau jumlah peserta didik sebanyakbanyaknya dengan hasil pendidikan sebesarbesarnya.

Prototipe aplikasi terminologi medis dan klasifikasi penyakit (ICD-10) merupakan salah satu sumber pembelajaran yang menggunakan media berbasis komputer. Penggunaan media pembelajaran berbasis teknologi informasi dan komunikasi akan mendukung keberhasilan pembelajaran, karena memiliki kelebihan-kelebihan sebagai berikut ${ }^{21}$ :

a. Dapat memberikan pemahaman yang lebih dalam terhadap materi pembelajaran yang sedang dibahas

b. Menarik dan membangkitkan perhatian, minat, motivasi, aktivitas, dan kreativitas belajar mahasiswa

c. Memancing partisipasi mahasiswa dalam proses pembelajaran dan memberikan kesan yang mendalam dalam pikiran peserta didik.

d. Materi pembelajaran yang sudah dipelajari dapat diulang kembali

e. Menciptakan lingkungan belajar yang kondusif, sehingga mahasiswa dapat berkomunikasi dan berinteraksi dengan lingkungan tempat belajarnya, sehingga memberikan pengalaman nyata dan langsung.

f. Mahasiswa dapat belajar sesuai dengan karakteristiknya, kebutuhan, minat, dan bakatnya, baik belajar secara individual, kelompok, atau klasikal

g. Menghemat waktu, tenaga, dan biaya

Elearning tidak untuk menggantikan pembelajaran di kelas tetapi merupakan peluang untuk berinteraksi dan berkomunikasi antara dosen dan mahasiswa $^{21}$. Aplikasi dengan bantuan komputer merupakan salah satu alat bantu dalam pembelajaran yang dapat meningkatkan pengetahuan, keterampilan serta merupakan salah satu metode yang efektif $^{4,5,6}$. Metode pembelajaran dengan pendekatan elearning merupakan salah satu metode pembelajaran berpusat mahasiswa (student centered learning) ${ }^{22}$. Manfaat dari aplikasi dengan bantuan komputer dan elearning adalah dapat meningkatkan kesenjangan antara pengajar dan peserta didik, dapat menjadi alat simulasi pemecahan masalah melalui studi kasus dan latihan yang didesain secara interaktif ${ }^{4,24}$. Selain itu konsep pembelajaran e-learning merupakan alternatif pembelajaran yang lebih efektif dan efisien dan merupakan konsep distance learning ${ }^{20,25}$. Konsep pembelajaran interaktif salah satunya adalah dilengkapi dengan latihan. Latihan dalam suatu aplikasi salah satunya adalah dalam bentuk kuis, kuis merupakan teknik yang dapat mendorong partisipasi mahasiswa dalam pembelajaran aktif ${ }^{23}$. Selain itu kuis atau ujian merupakan media untuk 
mengevaluasi hasil pembelajaran masingmasing peserta didik ${ }^{25}$.

Prototipe aplikasi terminologi medis dan ICD-10 dengan desain web disusun berdasarkan kerangka pikir bahwa aplikasi tersebut dapat digunakan untuk evaluasi keberhasilan pembelajaran serta dapat digunakan oleh seluruh mahasiswa D3 Rekam Medis, Dosen, petugas rekam medis di rumah sakit, maupun mahasiswa kedokteran dan keperawatan yang menginginkan pembelajaran terkait ICD-10. Pengetahuan merupakan proses dinamis yang berlangsung melalui proses terusmenerus dan memerlukan partisipasi aktif dari pembelajar ${ }^{23}$.

Dengan pemanfaatan teknologi informasi dalam pembelajaran klasifikasi dan kodefikasi penyakit dan masalah terkait, diharapkan dapat menjadi salah satu metode pembelajaran bagi mahasiswa, maupun petugas rekam medis. Sehingga kompetensi dapat tercapai sesuai dengan Kepmenkes 377 tahun 2007. Berdasarkan penelitian dari Haryoko ${ }^{27}$ dinyatakan bahwa pembelajaran di Fakultas Teknik Universitas Negeri Makasar diperoleh data bahwa pembelajaran dengan menggunakan media audio-visual lebih baik dibandingkan dengan pembelajaran melalui pendekatan konvensional. Oleh karena itu perlu ada perubahan paradigma dalam proses pembelajaran. Hal tersebut senada dengan penelitian dari Hasibuan \& Santosa ${ }^{28}$ yang menyatakan bahwa pembelajaran dengan pendekatan e-learning mendapatkan respon yang sangat baik dari mahasiswa. Serta menurut hasil penelitian dari Luthfi $^{29}$ menyatakan bahawa dengan adanya media e-Learning, e-Book, dan Web Blog telah terbukti menjadi alternatif bagi kalangan pendidikan dalam berinteraksi dalam proses pembelajaran serta pemanfaatan media teknologi informasi juga telah dianggap berhasil dalam meningkatkan motivasi dan minat belajar bagi para siswa atau mahasiswa.

Berdasarkan hasil analisis karakteristik responden diperoleh data bahwa tidak ada perbedaan yang bermakna antara persepsi kemudahan dan kemanfaatan jika dibandingkan dengan umur. Perbedaan umur pada dasarnya tidak berhubungan langsung terhadap kinerja seseorang dalam melaksanakan pekerjaannya. Pendapat ini didukung oleh pendapat Robbin ${ }^{26}$ yang menyebutkan bahwa tuntutan sebagian pekerjaan, bahkan pekerjaanpekerjaan yang mensyaratkan kerja otot yang berat, tidak cukup besar terpengaruh olehkemerosotan keterampilan akibat umur yang berdampak pada produktivitas. Ini menunjukkan bahwa perbedaan umur mahasiswa D3 Rekam Medis UGM tidak mempengaruhi persepsi kemanfaatan dan kemudahan dalam penggunaan aplikasi terminologi medis \& ICD-10 berbasis komputerisasi.Masrom ${ }^{22}$ memberikan informasi bahwa tidak ada hasil yang signifikan antara umur, jenis kelamin terkait evaluasi kemudahan dan kemanfaatan penggunaan aplikasi.

Pendapat senada juga disampaikan oleh Klopping \& Mc Kinney $\left(\operatorname{Smith}^{16}\right)$ yang telah melakukan survey pada 253 responden 
terkait persepsi kemudahan dan kemanfaatan terhadap penggunaan aplikasi berbasis web, 96\% berumur 20-25 tahun. Persentase umur 17-25 tahun pada penelitian berjumlah 116 mahasiswa $(96,7 \%)$. Hal tersebut dikarenakan pada umur 17-25 tahun adalah umur mahasiswa menempuh perkuliahan. Sisa dari responden pada penelitian ini adalah mahasiswa tugas belajar $(3,3 \%)$.

Di lain pihak umur merupakan faktor eksternal (user characteristic) dari populasi yang dapat memberikan variasi pada persepsi kemudahan dan kemanfaatan. Umur mengindikasikan dimulainya eksplorasi masalah berdasarkan cara pandangnya, banyak pengalaman, fungsi kognitif dan tingkat mobilisasi dari populasi yang lebih banyak dibandingkan dengan usia muda $\left(\right.$ Smith $\left.^{16}\right)$.

Robbin $^{37}$ menyatakan bahwa tidak ada perbedaan berarti dalam produktivitas pekerjaan antara laki-laki dan perempuan. Hal senada juga disampaikan oleh Masrom $^{22}$ bahwa jenis kelamin tidak membedakan persepsi kemudahan dan kemanfaatan. Hal ini menunjukkan bahwa tidak ada perbedaan persepsi mahasiswa D3 Rekam Medis UGM antara laki-laki dan perempuan dalam implementasi aplikasi terminologi medis dan klasifikasi penyakit (ICD10) berbasis komputerisasi terhadap kemudahan dan kemanfaatan. Penegasan juga disampaikan oleh Quinn at al., (Robbin ${ }^{37}$ ) bahwa tidak ada bukti yang menunjukkan jenis kelamin karyawan yang mempengaruhi kepuasan kerja.
Tingkat semester dari responden tidak berpengaruh pada penggunaan aplikasi terminologi medis dan ICD-10. hal ini dibuktikan dengan rata-rata dari kuesioner responden tiap semester dapat di lihat pada tabel 9 di bawah ini:

Tabel 9. Rata-rata persepsi kemudahan dan kemanfaatan

\begin{tabular}{|c|c|c|c|}
\hline No & Semester & Kemudahan & Kemanfaatan \\
\hline 1 & I & 4,01 & 4,24 \\
\hline 2 & III & 4,09 & 4,37 \\
\hline 3 & V & 4,23 & 4,36 \\
\hline
\end{tabular}

Berdasarkan tabel 9 di atas, rata-rata secara umum sama dan berdasarkan hasil analisis Anova menyatakan bahwa tidak ada perbedaan signifikan antara kemudahan dan kemanfaatan jika dibandingkan dengan tingkat semester. Hal senada juga disampaikan oleh Widoyoko ${ }^{38}$ jika hasil dari rata-rata persepsi lebih dari 4,2 maka dapat diklasifikasikan penggunaan aplikasi ini sangat baik (sangat mudah dan bermanfaat). akan tetapi dapat di lihat perbedaan persepsi kemudahan semester I dengan semester III sama, untuk semester V lebih tinggi. Hal ini dapat dibuktikan melalui hasil diskusi kelompok, bahwa mahasiswa semester I merasa sedikit kesulitan dikarenakan penggunaan baru satu kali dan apliaksi ini merupakan hal baru bagi mereka, untuk semester III lebih nyaman menggunakan dikarenakan sudah ada matakuliah terkait ICD-10,dan semester V sudah menyelesaikan matakuliah ICD-10. hal demikian juga terjadi pada persepsi 
kemanfaatan, semester III dan V lebih bermanfaat dikarenakan sudah mengambil matakuliah ICD-10, sedangkan semester I hanya matakuliah terminologi medis.

Tingkat kemudahan penggunaan sistem informasi yang berbasis komputer dipengaruhi oleh berbagai faktor. Salah satunya adalah pengalaman penggunaan komputer oleh pengguna. Iqbaria ${ }^{39}$ menyebutkan bahwa dukungan pengetahuan komputer secara intern organisasi (internal support) merupakan dukungan pengetahuan teknis yang dimiliki secara individual maupun secara kelompok mengenai pengetahuan komputer.

Tingkat keterampilan mahasiswa D3 Rekam Medis dalam penggunaan komputer cukup mendukung dalam implementasi aplikasi terminologi medis dan ICD-10 berbasis komputer sehingga dipercaya bermanfaat dalam proses pembelajaran. Hal ini ditunjukkan oleh hasil penelitian bahwa pada umumnya mahasiswa telah mempunyai komputer pribadi dengan frekuensi penggunaan yang cukup tinggi dan memiliki kemampuan aplikasi penggunaan komputer yang cukup baik.

Berdasarkan pengamatan peneliti di lapangan pada dasarnya mahasiswa tidak mengalami kendala berarti dalam penggunaan aplikasi terminologi medis \& ICD-10 sehingga secara umum mahasiswa mampu mengoperasikannya dimulai dari registrasi sampai kepada proses penentuan modul pembelajarandengan baik. Hal ini berarti pembelajaran dengan menggunakan komputer mudah dilaksanakan. Bedasarkan penelitian Rouse $^{17}$, dengan hasil penggunaan aplikasi multimedia pada materi penyakit jantung dapat meningkatkan kepahaman siswa perawat tentang penyakit jantung tersebut. Selain itu, instruksi belajar dengan bantuan komputer dengan suara, visual dan interaktifitas menjadikan multimedia sebagai pencipta lingkungan belajar interaktif yang meningkatkan intensitas proses belajar-mengajar. Sebagai kesimpulan dinyatakan bahwa pembelajaran dengan bantuan komputer ini merupakan strategi pembelajaran yang efektif dari segi biaya dan waktu.

Aplikasi terminologi medis dan klasifikasi penyakit (ICD-10) selain digunakan sebagai salah satu sumber belajar teoritis juga dapat digunakan sebagai materi praktek dalam menentukan terminologi, anatomi maupun kode ICD-10. Hari hasil diskusi kelompok, mahasiswa lebih senang jika penggunaan aplikasi ini sebagai alat pendidikan dan segera diterapkan dalam pembelajaran mereka. Hal ini sesuai dengan hasil penelitian Peckler $^{40}$ tentang penggunaan cara simulasi dalam ujian praktek klinis, yang dilakukan terhadap 117 mahasiswa kedokteran Universitas South Florida, menghasilkan bukti bahwa 98\% siswa mengisi diagnosis dengan benar; di samping itu siswa merasa lebih senang dengan sistem simulasi untuk ujian praktikum ini dan $88 \%$ setuju bahwa simulasi dapat digunakan sebagai alat pendidikan. Hal senada juga disampaikan oleh Teoh, et al., ${ }^{41}$ sikap siswa terhadap pendekatan pembelajran berbasis web sangat positif dan menjanjikan. Menurut beliau, penggunaan multimedia 
dapat meningkatkan pembelajaran sehingga menjadi salah satu alternatif sumber belajar. Selain itu, menurut Amstrong, et $a l^{42}$ penggunaan multimedia interaktif dapat digunakan sebagai metode pengajaran tambahan selain metode konvensional. Lingkungan paling cocok untuk para siswa adalah campuran dari kedua metode tersebut. Sehingga aplikasi terminologi medis dan klasifikasi penyakit (ICD-10) dapat digunakan sebagai sumber belajar tambahan metode pembelajaran yang disampaikan di kelas.

Jika persepsi kemanfaatan dan kemudahan tinggi, maka pengguna akan senang untuk tetap menggunakan kembali aplikasi, dan hasil dari penelitian mereka diperoleh kesimpulan bahwasannya persepsi kemudahan memiliki pengaruh yang kuat terhadap persepsi kemanfaatan (Hallegatte \& Nantel $^{43}$.Pendapat senada juga disampaikan oleh Klopping \& Mc Kinney $\left(\right.$ Smith $\left.^{16}\right)$ bahwa persepsi kemudahan dan kemanfaatan memiliki hubungan yang signifikan terhadap intensitas penggunaan aplikasi.Sedangkan Nugroho $^{13}$ menyatakan bahwa evaluasi kemudahan dan kemanfaatan digunakan untuk mengetahui reaksi pengguna terhadap sistem informasi.

Analisis peneliti bahwa di samping tingkat keterampilan penggunaan komputer mahasiswa yang telah memadai, tingkat kemudahan penggunaan (easy of use) aplikasi terminologi medis dan ICD-10 cukup mendukung kemanfaatan sistem yang dirasakan oleh mahasiswa. TAM ini diperkenalkan oleh Fred D. Davis yang mengembangkan adanya 2 faktor penting dalam memprediksi keberterimaan pengguna terhadap suatu teknologi baru, yaitu perceived usefulness (persepsi kemanfaatan) dan perceived ease of use (persepsi kemudahan) (Davis ${ }^{7}$ ). Davis mendefinisikan faktor kemanfaatan (usefulness) sebagai tingkat kepercayaan seseorang bahwa aplikasi tertentu akan meningkatkan kinerja mereka. Sedangkan faktor kemudahan (ease of use) adalah tingkat kepercayaan seseorang bahwa menggunakan aplikasi tertentu adalah mudah, tanpa kesulitan. Lebih lanjut disampaikan bahwa orang akan menggunakan atau tidak menggunakan terhadap suatu aplikasi teknologi-baru dipengaruhi oleh rasa percaya bahwa aplikasi tersebut bermanfaat terhadap kinerjanya. Oleh karena itu faktor kemanfaatan menjadi penting diperhitungkan dalam menguji keberterimaan suatu sistem baru. Namun, walaupun pengguna percaya bahwa aplikasi teknologi baru tersebut bermanfaat, belum tentu menerima aplikasi tersebut karena hal tersebut juga dipengaruhi oleh apakah penggunaan aplikasi tersebut harus dengan upaya keras, dengan kata lain sulit digunakan atau tidak. Oleh karena itu faktor kemudahan juga merupakan faktor penting dalam hal keberterimaan suatu aplikasi teknologi yang diterapkan

Mahasiswa yang merupakan pengguna aplikasi terminologi medis dan klasifikasi penyakit (ICD-10) berbasis komputer pada umumnya memberikan pendapat positif terhadap implementasi aplikasi ini karena merupakan 
suatu terobosan baru dan sangat bermanfaat (usefulness) dalam membantu mahasiswa akan pengetahuan terminologi medis \& ICD-10. Hasil dari penelitian ini menyebutkan bahwa persepsi mahasiswa akan kemudahan dan kemanfaatan cukup tinggi (dengan nilai rata-rata 4) yang menyatakan bahwa mahasiswa setuju bahwa palikasi tersebut mudah dan bermanfaat. Luma \& Zeqiri ${ }^{15}$ menyatakan bahwa teknologi yang menggunakan komputer, alat-alat elektronik dapat digunakan sebagai sumber informasi dan sebagai alternatif dalam mencari informasi. Hal senada diungkapkan oleh Nasution ${ }^{44}$ yang menyebutkan bahwa seseorang mempercayai dan merasakan dengan menggunakan komputer sangat membantu dan mempertinggi prestasi kerja yang akan dicapainya, atau dengan kata lain orang tersebut mempercayai penggunaan teknologi informatika telah memberikan manfaat terhadap pekerjaan dan pencapaian prestasi kerjanya.

Pengumpulan data pada penelitian ini selain dari kuesioner yang diolah secara kualitatif juga melakukan diskusi kelompok terfocus (focus group discussion = FGD). tujuan dari FGD pada penelitian ini adalah ingin mengumpulkan informasi terkait pengembangan prototipe aplikasi terminologi medis dan klasifikasi penyakit (ICD-10) dan mengetahui secara langsung dengan cara diskusi pada pengguna dalam hal ini adalah mahasiswa D3 Rekam Medis UGM terkait persepsi kemudahan dan kemanfaatan. Peserta FGD terdiri dari pakar dalam ilmu rekam medis, ilmu komputer dan mahasiswa. Hasil terkait pengembangan dari aplikasi ini adalah aplikasi sebaiknya dirancang lebih interaktif, baik materi maupun kuisnya. Selain itu usul yang terpenting adalah segera untuk dilengkapi datanya sehingga akan menjadi suatu aplikasi yang lebih lengkap. Hal ini sesuai kutipan diskusi seperti yang tersebut di bawah ini:

"Aplikasi ini sudah bagus dan lengkap, tetapi ada beberapa yang belum keliatan, akan tetapi lebih bagus lagi jika materi dilengkapi, dalam hal ini materi ICD-10 dapat dilengkapi informasi terkait konversi \& tanda baca, terdapat format untuk mengganti artikel (mengupdate). Kemampuan pencarian berdasarkan diagnosis dan kode ICD, adanya manajemen user sehingga dapat mengelola data pengguna secara baik. "Responden A.

"Sebelumnya saya beri apresiasi dulu, karena peneliti dengan bersusah payah merancang suatu aplikasi yang tentunya tidak mudah, web cukup menarik, akan tetapi akan jauh lebih baik lagi jika aplikasi dilengkapi dengan animasi, interaktifitas, seperti halnya video, suara, soal diacak agar lebih menarik. Selain itu pada menu administrator didesain juga secara interaktif, misalnya menu dapat diperbesar, dapat menambah video, suara dan animasi. Sehingga aplikasi ini akan menjadi suatu sistem elearning yang dapat digunakan oleh mahasiswa." Responden B. 
Hasil dari FGD tersebut akan dijadikan dasar untuk pengembangan aplikasi terminologi medis dan klasifikasi penyakit (ICD-10) lebih lanjut. Dalam hal ini peneliti membatasi bahwa aplikasi yang dijadikan penelitian hanya terbatas pada perancangan dan pengujian pada mahasiswa D3 Rekam Medis terkait persepsi kemudahan dan kemanfaatan dari penggunaan aplikasi terminologi medis dan klasifikasi penyakit (ICD-10).

\section{SIMPULAN}

1. Aplikasi terminologi medis dan klasifikasi penyakit (ICD-10) salah satu media pembelajaran pendamping pada matakuliah terminologi medis, ICD-10, anatomi, fisiologi, dan kuis interaktif serta dapat dijadikan salah satu upaya untuk mengurangi gap masalah dalam pembelajaran klasifikasi dan kodefikasi penyakit dan masalah terkait

2. Aplikasi terminologi medis dan klasifikasi penyakit (ICD-10) dapat dijadikan sumber pembelajaran secara umum tidak terbatas pada mahasiswa D3 Rekam Medis UGM.

\section{DAFTAR PUSTAKA}

1. Machfoedz, I., Suryani, E., Sutrisno, Santosa, S. (2005) Pendidikan Kesehatan Bagian Dari Promosi Kesehatan. Ed. 2. Yogyakarta: Fitramaya.

2. Glanz, K., Lewis, F.M., Rimer, B.K. (1996) Health Behavior and Health Education: theory, research, and practice. 2nd ed. San Fransisco: Jossey-Bass Publisher.
3. Pribadi, B.A. (2009) Model Desain Sistem Pembelajaran. Jakarta: Dian Rakyat

4. Zebrack, J.R, Mitchell, J.L, Davids, S.L, \& Simpson, D.E. (2005) Web-Based Curriculum: a practical and effective strategy for teaching women's health. Innovations In Education and Clinical Practice [Internet], June, 20 (1) pp. 68-74. Available from <http://www.pubmedcentral.gov $>$

5. Stern, D.T, Mangrulkar, R.S, Gruppen, L.D, Lang, A.L, Grum, C.M, Judge, R.D. (2001) Using a Multimedia Tool to Improve Cardiac Auscultation Knowledge and Skills. Jurnal General Medicine [Internet], November, 16 pp. 763-769. Available from <http://www.pubmedcentral.gov>

6. Gold, J.P., Begg, W.B., Fullerton, D., Mathisen, D., Olinger, G.,Orringer, M., Verrier, E. (2004) Succesful Implementation of a Novel Internet Hybrid Surgery Curriculum: The Early Phase Outcome of Thoracic Surgery Prerequisite Curriculum E-Learning Project. Annals of Surgery [Internet], September, 240 (3) pp. 499-509. Available from <http://www.pubmedcentral.gov>

7. Davis F. D. (1989) Perceived Usefulness, Perceived Ease Of Use and User Acceptance of Information Technology. Management Information System Quarterly [Internet], September, 13 (3) pp 318-340. Available from $<$ http://arladocent.eco.unicas.it $>$

8. Chaeruman, U. A. (2009) Pembelajaran Interaktif dengan Memanfaatkan Aneka Sumber Belajar [Internet]. Tersedia dalam:

<www.fakultasluarkampus.net/wpcontent/upload/2009>

9. Scoot, B.D. (2002) Teaching Technology. New York: Neal-Schuman Publisher.

10. Battles, J.B. (2006) Improving Patient Safety by Instructional Systems Design. USA: Agency for Health Research and Quality [Internet], May, 14 pp.125-129. Available from <http://www.qshc.com> 
11. Liu, S.H., Liao, H.L., Peng, C.J. (2005) Applying the Technology Acceptance Model and Flow Theory to Online ELearning User's Acceptance Behavior. Issues in Information Systems [Internet], 6 (2) pp: 175-181. Available from: <http://www.blackwell_sinergy.com>

12. Hatta, G. ed. (2008) Pedoman Manajemen Informasi Kesehatan Di Sarana Pelayanan Kesehatan. Jakarta: Universitas Indonesia Press.

13. Nugroho, E. (2008) Sistem Informasi Manajemen: Konsep, Aplikasi dan Perkembangannya.Yogyakarta: Andi Offset.

14. Nuryati (2010). Evaluasi Kemudahan dan Kemanfaatan Aplikasi Terminologi Medis dan Klasifikasi Penyakit (ICD-10). Tesis. Yogyakarta:Universitas Gadjah Mada

15. Luma, A. \& Zeqiri, N (2006) Development of the Interactive Multimedia Learning System and its Implementation [Internet]. Available from. <http://formatex.org>

16. Smith, T.J. (2008) Senior Citizens and ECommerce Website: The Role of Perceived Usefulness, Perceived Ease of Use, and Website Usability. The International Journal of an Emerging Transdicipline [Internet], Available from $<$ http://inform.nu>

17. Rouse, D.P. (1999) Creating an Interactive Multimedia ComputerAssisted instruction Program [Internet]. Computing Nurses, Jul-Aug, 17(4); 1716. Ohio: Raymond Walters College. Available from: <www.ncbi.nlm.nih.gov/pubmed/>

18. Mayer, R.E. (2009) Multimedia Learning: Prinsip-prinsip dan Aplikasi. Penyunting: Baroto Tavip Indrojarwo. Yogyakarta: Pustaka Pelajar.

19. Landry, B.J.L., Griffeth, R., Hartman, S. (2006) Measuring Student Perceptions of Blackboard Using the Technology Acceptance Model. Decision Sciences Journal of Innovative Education [Internet], Januari, 4 (1) pp: 87-99. Available from: <http://www.blackwell_sinergy.com>

20. Sa'ud, U.S. (2009) Inovasi Pendidikan.Bnadung: Alfabeta.

21. Munir. (2008) Kurikulum Berbasis Teknologi Informasi dan Komunikasi. Bandung: Alfabeta.

22. Masrom, M. (2007) Technology Acceptance Model and E-Learning. International Conference on Education [Internet]. Available from $\langle\underline{\text { http://eprints.utm.my }>}$

23. Harsono \& Dwiyanto, D. (2005) Pembelajaran Berpusat Mahasiswa. Yogyakarta: Pusat Pengembangan Pendidikan UGM.

24. Mc Kimm, J., Jollie, C., Cantillon, P. (2003) ABC of Learning and Teaching: web based learning. BMJ [Internet], April, 326 pp. 870-873. Available from <http://www.bmj.com>

25. Sanjaya, R \& Leong, M. (2008) ELearning. Yogyakarta: Universitas Atma Jaya

26. Santoso, H.B (2007) e Learning: Belajar Kapan Saja, Dimana Saja. Makasar: Universitas Hasanuddin.

27. Haryoko, S Efektivitas Pemanfaatan Media Audio-Visual Sebagai Alternatif Optimalisasi Model Pembelajaran. Jurnal Edukasi@Elektro. Makasar: Universitas Negeri Makasar.

28. Hasibuan, Z.A \& Santoso, H.B (2008) Analisis dan Perancangan Modul Representasi Knowledge Building Dalam Student Centered e Learning Environment. Jakarta: Universitas Indonesia

29. Luthfi, A (2010) Pemanfaatan Teknologi Web Sebagai Media Interaktif dan Pengembangan Terhadap Minat Belajar Bagi Mahasiswa. Jurnal Bina Edukasi. Palembang: Universitas Bina Darma

30. Kendall K.E., \& Kendall J.E. (2003) Analisis dan Perancangan Sistem, Alih Bahasa Thamin Abdul HA. Pearson Education Asia 
Pte Ltd: Jakarta.

31. Bryner, B.S. Daniel, S.K.,Thomas, R.G. (2008). The Impact of Interactive, Computerized Educational Modules on Preclinic Medical Education. Anatomy Science Education vol. 1(6) November $2008 . \quad$ Diakses dari www.ncbi.nlm.nih.gov/pubmed/

32. Whitten, J. L., Bentley, L. D \& Dittman, K. C (2004) Metode Desain dan Analisis Sistem, Yogyakarta: Andi Offset

33. Mahoney, D.F., Tarlow, B.J., Jones, R.N., Sandaire, J. (2002) Effects of a Multimedia Project on Users Knowledge about Normal Forgetting and Serious Memory Loss. Journal of the American Medical Informatics Association [Internet], Juli, 9 (4) pp. 383-394. Available from <http://www.pubmedcentral.gov>

34. Sabarguna, S.B \& Sungkar, A. (2007) Sistem Informasi Medis. Jakarta: UI Press

35. Kusminarto \& Rahayuningsih, E. (2005) Komputer Dalam Proses Pembelajaran. Yogyakarta: Pusat Pengembangan Pendidikan UGM

36. Utomo, B. \& Herdayati, M. (2003) Aplikasi ICD-10 dalam pemantauan upaya peningkatan kualitas pelayanan kesehatan reproduksi di dalam: Pormiki. Kumpulan Makalah Seminar Nasional dalam Kongres dan Rakernas I-III Pormiki. Jakarta: Pormiki, hal. 163-171.

37. Robbins, P.S. (2006) Perilaku Organisasi. Edisi Lengkap. PT. Indeks, Jakarta: Kelompok Gramedia.

38. Wijono, D. (1999) Manajemen Mutu Pelayanan Kesehatan : teori, strategi dan aplikasi. Vol. 2. Surabaya : Airlangga University Press

39. Igbaria M., Zinatelli N., Cragg P., \& Cavaye A L.M. (1997) Personal Computing Acceptance Factors in Small Firms: A StructuralEquation Model. MIS Quarterly 21(3). Available from: $\langle$ http://links.jstor.org/sici>
40. Pedkler, B. (2009). "Simulation in a High Stakes Clinical Performance Exam". Journal of Emergencies, Trauma and Shocks. 12:2, May-Aug 2009. Diakses dari www.onlinejets.org

41. Teoh, Belinda Soo-Phing, Tse-Kian Neo. (2007). "Interactive Multimedia Learning : Student's Attitudes and Learning Impact in An Animation Course". The Turkish Journal of Educational Technology, vol. 6 issue 4 article $3 . \quad$ Diakses dari www.tojet.net/articles/

42. Hallegatte, D. \& Nantel, J. (2004) The Intertwinned Effect of Perceived Usefulness, Perceived Ease of Use and Trust in a Website on the Intention to Return.[Internet]. Available from http://chairebc.com

43. Nasution F.N. (2004) Penggunaan Teknologi Informasi Berdasarkan Aspek Perilaku (Behavioral Aspect)[Internet].Available from: $\langle$ http://www. library. usu .ac. id $>$ 